\title{
Iodine chemistry in the troposphere and its effect on ozone
}

\author{
A. Saiz-Lopez ${ }^{1}$, R. P. Fernandez ${ }^{1, *}$, C. Ordóñez ${ }^{2}$, D. E. Kinnison ${ }^{3}$, J. C. Gómez Martín ${ }^{1, * *}$, J.-F. Lamarque ${ }^{3}$, and \\ S. Tilmes ${ }^{3}$ \\ ${ }^{1}$ Atmospheric Chemistry and Climate Group, Institute of Physical Chemistry Rocasolano, CSIC, Madrid 28006, Spain \\ ${ }^{2}$ Met Office, EX1 3PB, Exeter, UK \\ ${ }^{3}$ Atmospheric Chemistry Division, NCAR, Boulder, CO 80301, USA \\ *now at: National Research Council (CONICET), FCEN-UNCuyo, UTN-FRM, Mendoza 5501, Argentina \\ ${ }^{* *}$ now at: School of Chemistry, University of Leeds, LS2 9JT, Leeds, UK
}

Correspondence to: A. Saiz-Lopez (a.saiz@csic.es)

Received: 10 July 2014 - Published in Atmos. Chem. Phys. Discuss.: 1 August 2014

Revised: 30 October 2014 - Accepted: 5 November 2014 - Published: 10 December 2014

\begin{abstract}
Despite the potential influence of iodine chemistry on the oxidizing capacity of the troposphere, reactive iodine distributions and their impact on tropospheric ozone remain almost unexplored aspects of the global atmosphere. Here we present a comprehensive global modelling experiment aimed at estimating lower and upper limits of the inorganic iodine burden and its impact on tropospheric ozone. Two sets of simulations without and with the photolysis of $\mathrm{I}_{\mathrm{x}} \mathrm{O}_{\mathrm{y}}$ oxides (i.e. $\mathrm{I}_{2} \mathrm{O}_{2}, \mathrm{I}_{2} \mathrm{O}_{3}$ and $\mathrm{I}_{2} \mathrm{O}_{4}$ ) were conducted to define the range of inorganic iodine loading, partitioning and impact in the troposphere. Our results show that the most abundant daytime iodine species throughout the middle to upper troposphere is atomic iodine, with an annual average tropical abundance of (0.15-0.55) pptv. We propose the existence of a "tropical ring of atomic iodine" that peaks in the tropical upper troposphere $(\sim 11-14 \mathrm{~km})$ at the equator and extends to the sub-tropics $\left(30^{\circ} \mathrm{N}-30^{\circ} \mathrm{S}\right)$. Annual average daytime I / IO ratios larger than 3 are modelled within the tropics, reaching ratios up to $\sim 20$ during vigorous uplift events within strong convective regions. We calculate that the integrated contribution of catalytic iodine reactions to the total rate of tropospheric ozone loss $\left(\mathrm{IO}_{\mathrm{x} \text { Loss }}\right)$ is 2-5 times larger than the combined bromine and chlorine cycles. When $\mathrm{I}_{\mathrm{x}} \mathrm{O}_{\mathrm{y}}$ photolysis is included, $\mathrm{IO}_{\mathrm{x} \text { Loss }}$ represents an upper limit of approximately 27,14 and $27 \%$ of the tropical annual ozone loss for the marine boundary layer (MBL), free troposphere (FT) and upper troposphere (UT), respectively, while the lower limit throughout the tropical troposphere is $\sim 9 \%$. Our results indicate that iodine is the second strongest ozone-depleting family throughout the global marine UT and in the tropical MBL.
\end{abstract}

We suggest that (i) iodine sources and its chemistry need to be included in global tropospheric chemistry models, (ii) experimental programs designed to quantify the iodine budget in the troposphere should include a strategy for the measurement of atomic I, and (iii) laboratory programs are needed to characterize the photochemistry of higher iodine oxides to determine their atmospheric fate since they can potentially dominate halogen-catalysed ozone destruction in the troposphere.

\section{Introduction}

The oceans provide the main source of iodine to the atmosphere. Methyl iodide $\left(\mathrm{CH}_{3} \mathrm{I}\right)$ and other very short-lived (VSL) iodocarbons (e.g. $\mathrm{CH}_{2} \mathrm{I}_{2}, \mathrm{C}_{2} \mathrm{H}_{5} \mathrm{I}, \mathrm{C}_{3} \mathrm{H}_{7} \mathrm{I}, \mathrm{CH}_{2} \mathrm{ICl}$, $\mathrm{CH}_{2} \mathrm{IBr}$ ) are produced by biotic and photochemical processes, and released to the atmosphere from supersaturated ocean waters (Carpenter et al., 2012; Saiz-Lopez et al., 2012a). Laboratory studies have also established the gaseous emission of molecular iodine $\left(\mathrm{I}_{2}\right)$ following the reaction of aqueous iodide with atmospheric ozone at the sea surface (Garland and Curtis, 1981; Sakamoto et al., 2009; Hayase et al., 2010). More recently, it has been shown that HOI is the major species emitted as a result of this oxidative reaction (Carpenter et al., 2013; MacDonald et al., 2014). Several modelling studies and analysis of experimental data have suggested that the $\mathrm{HOI} / \mathrm{I}_{2}$ additional inorganic source must surpass the emission strength of organic VSL iodocarbons in order to reproduce observed iodine monoxide (IO) measure- 
Table 1. Iodine chemistry scheme in CAM-Chem: Bimolecular, thermal decomposition and termolecular reactions.

\begin{tabular}{|c|c|c|}
\hline Reaction & $k \mathrm{~cm}^{-3}$ molecule ${ }^{-1} \mathrm{~s}^{-1}$ & Notes \\
\hline $\mathrm{I}+\mathrm{O}_{3} \rightarrow \mathrm{IO}+\mathrm{O}_{2}$ & $2.1 \times 10^{-11} \mathrm{e}^{(-830 / T)}$ & 1 \\
\hline $\mathrm{IO}+\mathrm{O}_{3} \rightarrow \mathrm{OIO}+\mathrm{O}_{2}$ & $3.6 \times 10^{-16}$ & 2 \\
\hline $\mathrm{I}+\mathrm{HO}_{2} \rightarrow \mathrm{HI}+\mathrm{O}_{2}$ & $1.5 \times 10^{-11} \mathrm{e}^{(-1090 / T)}$ & 3 \\
\hline $\mathrm{IO}+\mathrm{NO} \rightarrow \mathrm{I}+\mathrm{NO}_{2}$ & $7.15 \times 10^{-12} \mathrm{e}^{(300 / T)}$ & 1 \\
\hline $\mathrm{IO}+\mathrm{HO}_{2} \rightarrow \mathrm{HOI}+\mathrm{O}_{2}$ & $1.4 \times 10^{-11} \mathrm{e}^{(540 / T)}$ & 1 \\
\hline $\mathrm{IO}+\mathrm{IO} \rightarrow \mathrm{OIO}+\mathrm{I}$ & $2.13 \times 10^{-11} \mathrm{e}^{(180 / T)} \times\left[1+\mathrm{e}^{(-p / 191.42)}\right]$ & 1,4 \\
\hline $\mathrm{IO}+\mathrm{IO} \rightarrow \mathrm{I}_{2} \mathrm{O}_{2}$ & $3.27 \times 10^{-11} \mathrm{e}^{(180 / T)} \times\left[1-0.65 \mathrm{e}^{(-p / 191.42)}\right]$ & 1,4 \\
\hline $\mathrm{IO}+\mathrm{OIO} \rightarrow \mathrm{I}_{2} \mathrm{O}_{3}$ & $\mathrm{w}_{1} \cdot \exp \left(\mathrm{w}_{2} \cdot T\right)^{\mathrm{a}}$ & $4,5,6^{\mathrm{g}}$ \\
\hline $\mathrm{OIO}+\mathrm{OIO} \rightarrow \mathrm{I}_{2} \mathrm{O}_{4}$ & $\mathrm{w}_{1} \cdot \exp \left(\mathrm{w}_{2} \cdot T\right)^{\mathrm{b}}$ & $4,5,6^{\mathrm{g}}$ \\
\hline $\mathrm{I}_{2}+\mathrm{O} \rightarrow \mathrm{IO}+\mathrm{I}$ & $1.25 \times 10^{-10}$ & 1 \\
\hline $\mathrm{IO}+\mathrm{O} \rightarrow \mathrm{I}+\mathrm{O}_{2}$ & $1.4 \times 10^{-10}$ & 1 \\
\hline $\mathrm{IO}+\mathrm{OH} \rightarrow \mathrm{HO}_{2}+\mathrm{I}$ & $1.0 \times 10^{-10}$ & 7 \\
\hline $\mathrm{I}_{2} \mathrm{O}_{2} \rightarrow \mathrm{OIO}+\mathrm{I}$ & $\mathrm{w}_{1} \cdot \exp \left(\mathrm{w}_{2} / T\right)^{\mathrm{c}}$ & $5,6,8^{\mathrm{g}}$ \\
\hline $\mathrm{I}_{2} \mathrm{O}_{2} \rightarrow \mathrm{IO}+\mathrm{IO}$ & $\mathrm{w}_{1} \cdot \exp \left(\mathrm{w}_{2} / T\right)^{\mathrm{d}}$ & $5,6,8^{\mathrm{g}}$ \\
\hline $\mathrm{I}_{2} \mathrm{O}_{4} \rightarrow 2 \mathrm{OIO}$ & $\mathrm{w}_{1} \cdot \exp \left(\mathrm{w}_{2} / T\right)^{\mathrm{e}}$ & $5,8^{\mathrm{g}}$ \\
\hline $\mathrm{I}_{2}+\mathrm{OH} \rightarrow \mathrm{HOI}+\mathrm{I}$ & $1.8 \times 10^{-10}$ & 3 \\
\hline $\mathrm{I}_{2}+\mathrm{NO}_{3} \rightarrow \mathrm{I}+\mathrm{IONO}_{2}$ & $1.5 \times 10^{-12}$ & 9 \\
\hline $\mathrm{I}+\mathrm{NO}_{3} \rightarrow \mathrm{IO}+\mathrm{NO}_{2}$ & $1.0 \times 10^{-10}$ & 1 \\
\hline $\mathrm{OH}+\mathrm{HI} \rightarrow \mathrm{I}+\mathrm{H}_{2} \mathrm{O}$ & $1.6 \times 10^{-11} \mathrm{e}^{(440 / T)}$ & 1 \\
\hline $\mathrm{I}+\mathrm{IONO}_{2} \rightarrow \mathrm{I}_{2}+\mathrm{NO}_{3}$ & $9.1 \times 10^{-11} \mathrm{e}^{(-146 / T)}$ & 5 \\
\hline $\mathrm{HOI}+\mathrm{OH} \rightarrow \mathrm{IO}+\mathrm{H}_{2} \mathrm{O}$ & $2.0 \times 10^{-13}$ & 10 \\
\hline $\mathrm{IO}+\mathrm{DMS} \rightarrow \mathrm{DMSO}+\mathrm{I}$ & $3.2 \times 10^{-13} \mathrm{e}^{(-925 / T)}$ & 11 \\
\hline $\mathrm{INO}_{2} \rightarrow \mathrm{I}+\mathrm{NO}_{2}$ & $1008 \times 10^{15} \mathrm{e}^{(-13670 / T)}$ & $12,13,14$ \\
\hline $\mathrm{IONO}_{2} \rightarrow \mathrm{IO}+\mathrm{NO}_{2}$ & $\mathrm{w}_{1} \cdot \exp \left(\mathrm{w}_{2} / T\right)^{\mathrm{f}}$ & 5,15 \\
\hline $\mathrm{INO}+\mathrm{INO} \rightarrow \mathrm{I}_{2}+2 \mathrm{NO}$ & $8.4 \times 10^{-11} \mathrm{e}^{(-2620 / T)}$ & 3 \\
\hline $\mathrm{INO}_{2}+\mathrm{INO}_{2} \rightarrow \mathrm{I}_{2}+2 \mathrm{NO}_{2}$ & $4.7 \times 10^{-13} \mathrm{e}^{(-1670 / T)}$ & 1 \\
\hline $\mathrm{OIO}+\mathrm{NO} \rightarrow \mathrm{IO}+\mathrm{NO}_{2}$ & $1.1 \times 10^{-12} \mathrm{e}^{(542 / T)}$ & 14 \\
\hline $\mathrm{HI}+\mathrm{NO}_{3} \rightarrow \mathrm{I}+\mathrm{HNO}_{3}$ & $1.3 \times 10^{-12} \mathrm{e}^{(-1830 / T)}$ & 16 \\
\hline $\mathrm{IO}+\mathrm{BrO} \rightarrow \mathrm{Br}+\mathrm{I}+\mathrm{O}_{2}$ & $0.30 \times 10^{-11} \mathrm{e}^{(510 / T)}$ & 1 \\
\hline $\mathrm{IO}+\mathrm{BrO} \rightarrow \mathrm{Br}+\mathrm{OIO}$ & $1.20 \times 10^{-11} \mathrm{e}^{(510 / T)}$ & 1 \\
\hline $\mathrm{I}+\mathrm{BrO} \rightarrow \mathrm{IO}+\mathrm{Br}$ & $1.44 \times 10^{-11}$ & $17,18,19$ \\
\hline $\mathrm{IO}+\mathrm{ClO} \rightarrow \mathrm{I}+\mathrm{OClO}$ & $2.585 \times 10^{-12} \mathrm{e}^{(280 / T)}$ & 1 \\
\hline $\mathrm{IO}+\mathrm{ClO} \rightarrow \mathrm{I}+\mathrm{Cl}+\mathrm{O}_{2}$ & $1.175 \times 10^{-12} \mathrm{e}^{(280 / T)}$ & 1 \\
\hline $\mathrm{IO}+\mathrm{ClO} \rightarrow \mathrm{ICl}+\mathrm{O}_{2}$ & $0.940 \times 10^{-12} \mathrm{e}^{(280 / T)}$ & 1 \\
\hline $\mathrm{IO}+\mathrm{Br} \rightarrow \mathrm{I}+\mathrm{BrO}$ & $2.49 \times 10^{-11}$ & 18,19 \\
\hline $\mathrm{IO}+\mathrm{NO}_{3} \rightarrow \mathrm{OIO}+\mathrm{NO}_{2}$ & $9.0 \times 10^{-12}$ & 20 \\
\hline $\mathrm{IO}+\mathrm{CH}_{3} \mathrm{O}_{2} \rightarrow \mathrm{CH}_{2} \mathrm{O}+\mathrm{I}+\mathrm{HO}_{2}$ & $2.0 \times 10^{-12}$ & $2^{\mathrm{h}}$ \\
\hline
\end{tabular}

ments over the open ocean environment (Jones et al., 2010; Mahajan et al., 2010, 2012; Gómez Martín et al., 2013b; Großmann et al., 2013; Lawler et al., 2014).

Early pioneering work by Chameides and Davis (1980) and Solomon et al. (1994) showed that both organic and inorganic iodine compounds photo-dissociate rapidly in the troposphere to release iodine atoms, which then react mainly with ozone to generate IO. A steady state is then established between I and IO as a result of the fast photolysis of the oxide, and therefore the two species are termed collectively as reactive iodine, or $\mathrm{IO}_{\mathrm{x}}=\mathrm{I}+\mathrm{IO}$. The $\mathrm{IO}_{\mathrm{x}}$ react further with other species to generate different forms of inorganic iodine (Saiz-Lopez et al., 2012a, see Table 1). The at- mospheric chemical processing of iodine species influences the oxidizing capacity of the troposphere through catalytic ozone-depleting cycles $\left(\mathrm{IO}_{\mathrm{x}}\right.$ Loss, i.e. Chameides and Davis, 1980; Solomon et al., 1994; Davis et al., 1996; Vogt et al., 1999; McFiggans et al., 2000; Brasseur and Solomon, 2005) and changes to the $\mathrm{HO}_{\mathrm{x}}$ (i.e. $\left[\mathrm{HO}_{2}\right] /[\mathrm{OH}]$ ) and $\mathrm{NO}_{\mathrm{x}}$ (i.e. $\left[\mathrm{NO}_{2}\right] /[\mathrm{NO}]$ ) ratios (Bloss et al., 2005). It also makes a negative contribution to the radiative flux in the tropical troposphere (Saiz-Lopez et al., 2012b), and produces higher-order iodine oxides $\left(\mathrm{I}_{\mathrm{x}} \mathrm{O}_{\mathrm{y}}\right)$ which have been proposed to participate in the formation of ultrafine aerosol particles in coastal environments (Hoffmann et al., 2001; O'Dowd et al., 2002; Jimenez et al., 2003; McFiggans et al., 2004, 2010; Pechtl et 
Table 1.

\begin{tabular}{lll}
\hline Reaction & $k \mathrm{~cm}^{-3}$ molecule $\mathrm{s}^{-1}$ & Notes \\
\hline $\mathrm{CH}_{3} \mathrm{I}+\mathrm{OH} \rightarrow \mathrm{I}+\mathrm{H}_{2} \mathrm{O}+\mathrm{HO}_{2}$ & $2.90 \times 10^{-12} \mathrm{e}^{(-1100 / T)}$ & 3 \\
$\mathrm{I}+\mathrm{NO}_{2}(+\mathrm{M}) \rightarrow \mathrm{INO}_{2}(+\mathrm{M})$ & $k_{0}=3 \times 10^{-31} \times(T / 300)^{-1}$ & $3^{\mathrm{i}}$ \\
& $k_{\infty}=6.6 \times 10^{-11}$ & \\
$\mathrm{IO}+\mathrm{NO}_{2}(+\mathrm{M}) \rightarrow \mathrm{IONO}_{2}(+\mathrm{M})$ & $k_{0}=6.5 \times 10^{-31} \times(T / 300)^{-3.5}$ & $3^{\mathrm{i}}$ \\
& $k_{\infty}=7.6 \times 10^{-12} \times(T / 300)^{-1.5}$ & $3^{\mathrm{i}}$ \\
$\mathrm{I}+\mathrm{NO}(+\mathrm{M}) \rightarrow \mathrm{INO}(+\mathrm{M})$ & $k_{0}=1.8 \times 10^{-32} \times(T / 300)^{-1}$ & \\
& $k_{\infty}=1.7 \times 10^{-11}$ & \\
$\mathrm{OIO}+\mathrm{OH}(+\mathrm{M}) \rightarrow \mathrm{HOIO}_{2}(+\mathrm{M})$ & $k_{0}=1.5 \times 10^{-27} \times(T / 300)^{-3.93}$ & \\
\hline
\end{tabular}

${ }_{5}^{1}$ IUPAC-2008 (Atkinson et al., 2007); ${ }^{2}$ Dillon et al., 2006b; ${ }^{3}$ JPL-2010 (Sander et al., 2011); ${ }^{4}$ Gómez Martín et al., 2007; ${ }^{5}$ Kaltsoyannis and Plane, 2008; ${ }^{6}$ Gálvez et al., 2013; ${ }^{7}$ Bösch et al., 2003; ${ }^{8}$ Gómez Martín and Plane, 2009; ${ }^{9}$ Chambers et al., 1992; ${ }^{10}$ Chameides and Davis, 1980; ${ }^{11}$ Dillon et al., 2006a; ${ }^{12}$ McFiggans et al., 2000; ${ }^{13}$ Jenkin et al., $1985 ;{ }^{14}$ Plane et al., 2006; ${ }^{15}$ Allan and Plane, 2002; ${ }^{16}$ Lancar et al., 1991; ${ }^{17}$ Laszlo et al., 1997; ${ }^{18}$ Bedjanian et al., 1997; ${ }^{19}$ Gilles et al., 1997; ${ }^{20}$ Dillon et al., 2008.

$\mathrm{a}_{\mathrm{w} 1}=4.687 \times 10^{-10}-1.3855 \times 10^{-5} \times \mathrm{e}^{(-0.75 p / 1.62265)}+5.51868 \times 10^{-10} \times \mathrm{e}^{(-0.75 p / 199.328)}$ $\mathrm{w} 2=-0.00331-0.00514 \times \mathrm{e}^{(-0.75 p / 325.68711)}-0.00444 \times \mathrm{e}^{(-0.75 p / 40.81609)}$

$\mathrm{b}_{\mathrm{w} 1}=1.1659 \times 10^{-9}-7.79644 \times 10^{-10} \mathrm{e}^{(-0.75 p / 22.09281)}+1.03779 \times 10^{-9} \times \mathrm{e}^{(-0.75 p / 568.15381)}$

$\mathrm{w} 2=-0.00813-0.00382 \times \mathrm{e}^{(-0.75 p / 45.57591)}-0.00643 \times \mathrm{e}^{(-0.75 p / 417.95061)}$

$\mathrm{c}_{\mathrm{w} 1}=3.54288 \times 10^{10}+1.8523 \times 10^{11} \times 0.75 p-1.45435 \times 10^{8} \times(0.75 p)^{2}+60799.4344 \times(0.75 p)^{3}$

$\mathrm{w} 2=-9681.65989+346.95538 \times \mathrm{e}^{(-0.75 p / 343.25322)}+251.78032 \times \mathrm{e}^{(-0.75 p / 44.1466)}$

$\mathrm{d}_{\mathrm{w} 1}=255335000000-4418880000 \times 0.75 p+85618600 \times(0.75 p)^{2}+14218.81 \times(0.75 p)^{3}$

$\mathrm{w} 2=-11466.82304+597.01334 \times \mathrm{e}^{(-0.75 p / 1382.62325)}-167.3391 \times \mathrm{e}^{(-0.75 p / 43.75089)}$

$\mathrm{e}_{\mathrm{w} 1}=-1.92626 \times 10^{14}+4.67414 \times 10^{13} \times 0.75 p-3.68651 \times 10^{8} \times(0.75 p)^{2}-3.09109 \times 10^{6} \times(0.75 p)^{3}$

$\mathrm{w} 1=-1.92626 \times 10+4.6783 \times 1 \mathrm{e}^{(-0.75 p / 46.12733)}+437.62868 \times \mathrm{e}^{(-0.75 p / 428.4413)}$

${ }_{\mathrm{f}} \mathrm{w} 1=-2.63544 \times 10^{13}+4.32845 \times 10^{12} \times(0.75 p)+3.73758 \times 10^{8} \times(0.75 p)^{2}-628468.76313 \times(0.75 \mathrm{p})^{3}$

$\mathrm{w} 2=-13847.85015+240.34465 \times \mathrm{e}^{(-0.75 p / 49.27141)}+451.35864 \times \mathrm{e}^{(-0.75 p / 436.87605)}$

$\mathrm{g}$ The empirical expressions of the form $\mathrm{w}_{1} \cdot \exp \left(\mathrm{w}_{2} \cdot T\right)$ were obtained by non-linear least squares fitting of

Rice-Ramsperger-Kassel-Marcus (RRKM) theoretical results for the indicated reaction rate constants and thermal dissociation rates in the (27-1013) hPa pressure range. RRKM calculations were carried out using the MESMER algorithm (Glowacki et al., 2012) as indicated in the corresponding references (e.g. Gálvez et al., 2013). Expression a produces negative values outside the range of modelled rate constants $\left(p<20 \mathrm{hPa}\right.$ ), and therefore a fixed rate constant of $3 \times 10^{-11} \mathrm{~cm}^{3}$ molecule ${ }^{-1} \mathrm{~s}^{-1}$ was assumed. Expressions ${ }^{\mathrm{e}}$ and ${ }^{\mathrm{f}}$ generate negligible dissociation rates below $\sim 500 \mathrm{hPa}$ which become negative at $\sim 8 \mathrm{hPa}-$ in this case they are set to zero below that pressure. Note that the parametrized pressure range of rate constants spans the atmospheric layer relevant for this work and beyond (see Figs. 3 and 4)

${ }_{\mathrm{h}}$ Updated heats of formation for IO, OIO, and $\mathrm{CH}_{3} \mathrm{O}_{2}$ (Dooley et al., 2008; Gómez Martín and Plane, 2009; Knyazev and Slagle, 1998) show that the only accessible exothermic product channel of $\mathrm{CH}_{3} \mathrm{O}_{2}+\mathrm{IO}$ (Drougas and Kosmas, 2007) is $\mathrm{CH}_{3} \mathrm{O}+\mathrm{I}+\mathrm{O}_{2}$

$\left(\Delta \mathrm{H}_{\mathrm{r}}=-5 \pm 6 \mathrm{~kJ} \mathrm{~mol}^{-1}\right)$, consistent with the high yield of I and low yield of OIO found experimentally (Bale et al., 2005; Enami et al., 2006). Sensitivity studies have been carried out using the preferred rate constant for this reaction of

$2 \times 10^{-12} \mathrm{~cm}^{3}$ molecule ${ }^{-1} \mathrm{~s}^{-1}$ (Dillon et al., 2006b), resulting in an enhancement of the ozone loss of $0.5 \%$ in the MBL and of less than $0.1 \%$ integrated throughout the troposphere in the $J_{\mathrm{I}_{\mathrm{X}}} \mathrm{O}_{\mathrm{y}}$ scenario, and similarly negligible enhancements in the Base scenario. Impacts in the $\mathrm{I}_{\mathrm{y}}$ partitioning are also very minor.

${ }^{\mathrm{i}}$ The temperature and pressure dependent rate constant $(k)$ is computed based on the low pressure $\left(\mathrm{k}_{0}\right)$ and the high-pressure $\left(k_{\infty}\right)$ rate coefficients following JPL-2010 (Sander et al., 2011).

${ }^{j}$ The fast rate constants and a thermally stable product $\mathrm{HOIO}_{2}$ have been predicted theoretically (Plane et al., 2006), but no experimental studies reporting observation of $\mathrm{HOIO}_{2}$ and its photochemical properties in the gas phase are available. Since the level of uncertainty is even larger than for the $\mathrm{I}_{\mathrm{x}} \mathrm{O}_{\mathrm{y}}$, it has not been included in the mechanism.

al., 2006; Saiz-Lopez et al., 2006; Huang et al., 2010; Mahajan et al., 2011; Atkinson et al., 2012).

Different techniques have enabled measurements of tropospheric iodine species in geographical locations ranging from the tropical troposphere to the polar boundary layer (Saiz-Lopez and von Glasow, 2012). Comprehensive reports and inventories of organic VSL iodocarbons across the world oceans have been published in the last decades (Saiz-Lopez et al., 2012a, and references therein). Inorganic reactive iodine species have been observed in the marine boundary layer (MBL) well above their detection limits, including IO (Alicke et al., 1999), OIO (Allan et al., 2000), I 2 (Saiz-Lopez and Plane, 2004), and I (Bale et al., 2008). More recently, the detection of IO in the sub-tropical (Puentedura et al.,
2012) and tropical (Dix et al., 2013) free troposphere shows a widespread presence of active iodine species throughout the marine troposphere.

Based on iodine's faster catalytic ozone-depletion kinetics compared to that of bromine and chlorine, box- and one/two-dimensional (Solomon et al., 1994; Davis et al., 1996; Vogt et al., 1999; Calvert and Lindberg, 2004; Saiz-Lopez et al., 2007; Sommariva and von Glasow, 2012; Sommariva et al., 2012) and global (Saiz-Lopez et al., 2012b) modelling studies have suggested the potential important role of iodine in the destruction of tropospheric ozone. Additionally, recent studies have pointed out differences between observed and modelled $\mathrm{O}_{3}$ abundances in the tropical upper troposphere (Young et al., 2013) and northern mid-latitude lower 
troposphere (Parrish et al., 2014), and highlighted the importance of performing a rigorous investigation of additional factors driving the budget of tropospheric ozone. Following the evidence of the ubiquitous presence of reactive iodine in the troposphere, we present simulations with a chemistryclimate model that includes geographically distributed VSL iodocarbon sources $\left(\mathrm{CH}_{3} \mathrm{I}, \mathrm{CH}_{2} \mathrm{I}_{2}, \mathrm{CH}_{2} \mathrm{ICl}\right.$ and $\left.\mathrm{CH}_{2} \mathrm{IBr}\right)$ as well as global inorganic iodine emissions $\left(\mathrm{HOI} / \mathrm{I}_{2}\right)$ from the oceans. The model includes a state-of-the-art iodine chemistry scheme considering $\mathrm{I}_{\mathrm{x}} \mathrm{O}_{\mathrm{y}}$ and their photolytic and thermal decomposition, individualized wet-removal processes and ice-uptake, as well as heterogeneous recycling reactions over sea-salt aerosol and ice particles. Here we highlight, for the first time in a global model, some of the unique aspects of iodine chemistry that drive the partitioning of organic and inorganic iodine species throughout the troposphere. The $\mathrm{I}_{\mathrm{x}} \mathrm{O}_{\mathrm{y}}$ represent a substantial mass of atmospheric iodine currently unaccounted for and subject to a large degree of uncertainty. The upper and lower limits of the tropospheric iodine burden are shown to be strongly dependent on the uncertainties related to the chemical fate of $\mathrm{I}_{\mathrm{x}} \mathrm{O}_{\mathrm{y}}$ species, whose photochemistry and reactivity represent a fundamental problem in our current knowledge of iodine chemistry and its effects in the atmosphere. Based on our results, we discuss implications for the transport and partitioning of iodine species to the free troposphere (FT) and upper troposphere (UT), and assess its relevance on the tropospheric ozone budget.

\section{Model description: CAM-Chem setup}

The global 3-D chemistry climate model CAM-Chem (Community Atmospheric Model with Chemistry, version 4.0), included into the CESM framework (Community Earth System Model, version 1.1.1) was used for this study (Lamarque et al., 2012). CAM-Chem can be configured at different grid resolutions and dynamical configurations. The setup used here considers a horizontal grid resolution of $1.9^{\circ}$ (latitude) $\times 2.5^{\circ}$ (longitude) and 26 hybrid vertical levels from the surface to approximately $40 \mathrm{~km}$. CAM-Chem has the capability to perform simulations using specified dynamics (SD), where offline meteorological fields are used to compute the atmospheric transport. In order to eliminate dynamical alterations between simulations with dissimilar chemical mechanisms, we performed all simulations in SD mode, considering the same high-frequency meteorological input from a previous CAM-Chem 15-year simulation without halogen chemistry. In this way, our CAM-Chem setup implies that we force the system to evolve as if it was a CTM (chemical transport model), in a manner that the chemical changes existent at different locations and altitudes between a set of independent simulations can be directly addressed. See Lamarque et al. (2012) for a complete description of the SD setup.

The development of the benchmark CAM-Chem mechanism is based on MOZART-4 (Emmons et al., 2010). For

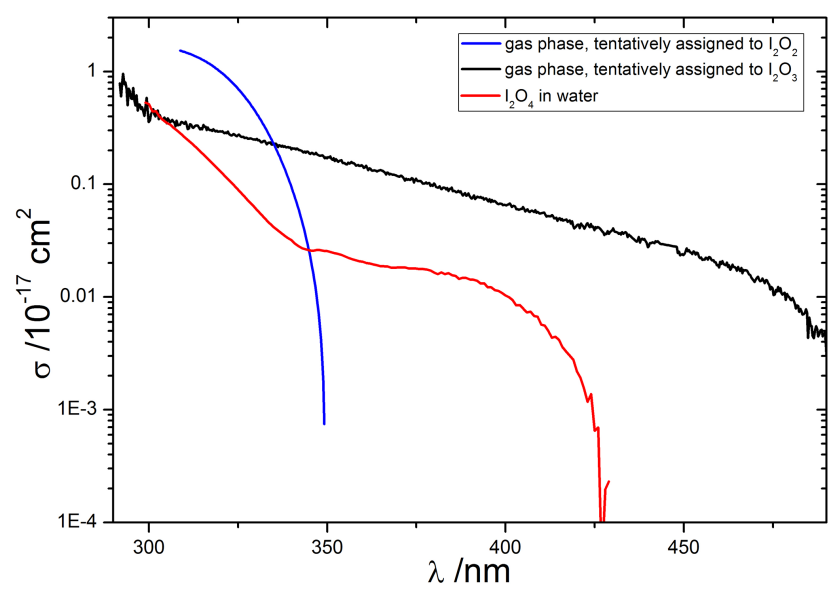

Figure 1. Absorption cross-sections of the higher iodine oxides $\mathrm{I}_{\mathrm{x}} \mathrm{O}_{\mathrm{y}}(x=2, y \geq 2)$. Gas phase experimental spectra tentatively assigned to $\mathrm{I}_{2} \mathrm{O}_{2}$ and $\mathrm{I}_{2} \mathrm{O}_{3}$ (Gómez Martín et al., 2005, 2007; Spietz et al., 2005) are plotted in blue and black respectively. The $\mathrm{I}_{2} \mathrm{O}_{2}$ spectrum has been smoothed by fitting a polynomial through it. The red line corresponds to the absorption spectrum of $\mathrm{I}_{2} \mathrm{O}_{4}$ in water (Russell Saunders, personal communication).

this configuration, an improved representation of stratospheric chemistry, considering heterogeneous processes in polar clouds from MOZART-3 (Kinnison et al., 2007; Wegner et al., 2013), has also been used. The chemical solver is initialized with identical chemical boundary conditions for any given species in all simulations presented here, and all the atmospheric oxidants are computed online at all times (i.e. without considering prescribed monthly $\mathrm{OH}$ fields as done in previous studies). Our current setup includes an organic and inorganic halogen (chlorine, bromine and iodine) photochemistry mechanism, considering both natural and anthropogenic sources, heterogeneous recycling, dry and wet deposition - both in the troposphere and lower stratosphere (Ordóñez et al., 2012; Fernandez et al., 2014). For iodine species we have compiled a state-of-the-art chemical scheme as described below.

\subsection{Atmospheric chemistry of iodine}

The chemistry of chlorine and bromine VSL species in CAM-Chem has been described in detail previously (Ordóñez et al., 2012; Fernandez et al., 2014). In this work we have used the same emissions inventory of bromo- $\left(\mathrm{CHBr}_{3}\right.$, $\mathrm{CH}_{2} \mathrm{Br}_{2}, \mathrm{CH}_{2} \mathrm{BrCl}, \mathrm{CHBr}_{2} \mathrm{Cl}$ and $\mathrm{CHBrCl}_{2}$ ) and iodocarbons presented there, extending the iodine inorganic chemistry mechanism. VSL oceanic sources of $\mathrm{CH}_{2} \mathrm{I}_{2}, \mathrm{CH}_{2} \mathrm{ICl}$ and $\mathrm{CH}_{2} \mathrm{IBr}$ are based on parametrizations of chlorophyll$a$ satellite maps, including latitudinal variations between $50^{\circ} \mathrm{N}-50^{\circ} \mathrm{S}$, a time-dependent ice-mask for polar oceans and a monthly seasonality (see Ordóñez et al. (2012) for details). The global $\mathrm{CH}_{2} \mathrm{IX}$ (with $\mathrm{X}=\mathrm{Cl}, \mathrm{Br}$ or I) flux in the model is $\sim 437 \mathrm{Gg} \mathrm{yr}^{-1}$. $\mathrm{CH}_{3} \mathrm{I}$ emissions are taken from 
an existing top-down inventory (Bell et al., 2002), which included major oceanic sources $\left(213 \mathrm{Gg} \mathrm{yr}^{-1}\right)$ as well as some land-based fluxes from rice paddies, wetlands, biofuel and biomass burning $\left(91 \mathrm{Gg} \mathrm{yr}^{-1}\right)$, yielding a global $\mathrm{CH}_{3} \mathrm{I}$ flux of $304 \mathrm{Gg} \mathrm{yr}^{-1}$. For the emissions of most VSL iodocarbons we follow a solar diurnal profile, with emissions peak in the early afternoon and null emissions at night. The exception is $\mathrm{CH}_{2} \mathrm{I}_{2}$ which showed an improved agreement with measurements when $\sim 1 / 4$ of the total emissions occurs during the night (Ordóñez et al., 2012). In addition, inorganic iodine oceanic sources have been included in the lowest layer of the model ( $\sim 150 \mathrm{~m}$ depth), based on recent laboratory studies that determined the abiotic gaseous emission of HOI and $\mathrm{I}_{2}$ following the oxidation of aqueous iodide by atmospheric ozone on the ocean surface (Carpenter et al., 2013; MacDonald et al., 2014). The global modelled emissions of HOI / $\mathrm{I}_{2}$ account for $\sim 1.9 \mathrm{Tg}$ (I) $\mathrm{yr}^{-1}$ and depend on the deposition of tropospheric ozone to the ocean surface, the sea surface temperature and the wind speed (see Prados-Roman et al. (2014) for further details on the implementation of the inorganic iodine source). This additional inorganic source is somewhat larger than the $\sim 1.2 \mathrm{Tg}$ (I) $\mathrm{yr}^{-1}$ value of Saiz-Lopez et al. (2012b) and within the range of values required to reconcile IO measurements in the MBL at coastal sites (i.e. in the range of (10-70) $\times 10^{7}$ atoms (I) $\mathrm{cm}^{-2} \mathrm{~s}^{-1}$; see Mahajan et al. (2010); Großmann et al. (2013) and references therein). The computed lifetimes of $\mathrm{CH}_{2} \mathrm{ICl}, \mathrm{CH}_{2} \mathrm{IBr}$ and $\mathrm{CH}_{2} \mathrm{I}_{2}$ range from minutes to hours in agreement with previous studies (Rattigan et al., 1997; Roehl et al., 1997; Mössinger et al., 1998), while for $\mathrm{CH}_{3} \mathrm{I}$ it is in the order of 5-8 days (Rattigan et al., 1997; Roehl et al., 1997).

Table 1 presents the bimolecular, thermal decomposition and termolecular reactions of iodine species included in the chemical mechanism. Updates with respect to previous analyses (Ordóñez et al., 2012; Saiz-Lopez et al., 2012b) are mainly based on theoretical studies on the formation, photochemistry and thermal decomposition of higher iodine oxides, collectively called $\mathrm{I}_{\mathrm{x}} \mathrm{O}_{\mathrm{y}}$ (Gómez Martín et al., 2007; Kaltsoyannis and Plane, 2008; Gómez Martín and Plane, 2009). A distinct feature of iodine chemistry, with respect to the other halogens, is the formation of $\mathrm{I}_{\mathrm{x}} \mathrm{O}_{\mathrm{y}}$ (where usually $x=2$ and $y=2,3$, or 4) from recombination reactions of IO with itself $(y=2)$ and with OIO $(y=3)$, or OIO with itself $(y=4)$. Unambiguous discriminated observation of $\mathrm{I}_{\mathrm{x}} \mathrm{O}_{\mathrm{y}}$ has been achieved only recently by means of photoionization time-of-flight mass spectrometry (Gómez Martín et al., 2013a). This recent work also confirmed the minor role played by ozone in the formation of iodine aerosol (Saunders et al., 2010), which rules out $\mathrm{I}_{2} \mathrm{O}_{5}$ as nucleating species (Saunders and Plane, 2005). Some other iodine oxides with different I / O stoichiometry $(x \neq 2)$ have been suggested to participate in complex mechanisms of particle formation (Gálvez et al., 2013; Gómez Martín et al., 2013a), albeit considerable uncertainty still exists about the chemistry and spectroscopy of these higher iodine oxides.
Table 2. Iodine chemistry scheme in CAM-Chem: photochemical reactions.

\begin{tabular}{l}
\hline Reaction \\
\hline $\mathrm{CH}_{3} \mathrm{I}+h v \rightarrow \mathrm{CH}_{3} \mathrm{O}_{2}+\mathrm{I}$ \\
$\mathrm{CH}_{2} \mathrm{I}_{2}+h v \rightarrow 2 \mathrm{I}^{\mathrm{a}}$ \\
$\mathrm{CH}_{2} \mathrm{IBr}+h v \rightarrow \mathrm{Br}+\mathrm{I}^{\mathrm{a}}$ \\
$\mathrm{CH}_{2} \mathrm{ICl}+h v \rightarrow \mathrm{Cl}+\mathrm{I}^{\mathrm{a}}$ \\
$\mathrm{I}_{2}+h v \rightarrow 2 \mathrm{I}$ \\
$\mathrm{IO}+h v \rightarrow \mathrm{I}+\mathrm{O}$ \\
$\mathrm{OIO}+h v \rightarrow \mathrm{I}+\mathrm{O}_{2}$ \\
$\mathrm{INO}+h v \rightarrow \mathrm{I}+\mathrm{NO}$ \\
$\mathrm{INO}_{2}+h v \rightarrow \mathrm{I}+\mathrm{NO}_{2}^{\mathrm{b}}$ \\
$\mathrm{IONO}_{2}+h v \rightarrow \mathrm{I}+\mathrm{NO}_{3}$ \\
$\mathrm{HOI}+h v \rightarrow \mathrm{I}+\mathrm{OH}$ \\
$\mathrm{IBr}+h v \rightarrow \mathrm{I}+\mathrm{Br}$ \\
$\mathrm{ICl}+h v \rightarrow \mathrm{I}+\mathrm{Cl}$ \\
$\mathrm{I}_{2} \mathrm{O}_{2}+h v \rightarrow \mathrm{I}+\mathrm{OIO}$ \\
$\mathrm{I}_{2} \mathrm{O}_{3}+h v \rightarrow \mathrm{IO}+\mathrm{OIO}^{\mathrm{c}}$ \\
$\mathrm{I}_{2} \mathrm{O}_{4}+h v \rightarrow \mathrm{OIO}+\mathrm{OIO}^{\mathrm{c}}$ \\
\hline
\end{tabular}

Photolysis rates are computed online considering the actinic flux calculation in CAM-Chem. The absorption cross-sections and quantum yields for all species besides the $\mathrm{I}_{\mathrm{X}} \mathrm{O}_{\mathrm{y}}$ have been taken from IUPAC-2008 (Atkinson et al., 2007, 2008) and JPL-2010 (Sander et al., 2011).

${ }^{a}$ Radical organic products are not considered.

$\mathrm{b}$ Only the reaction channel reported in JPL 06-02 (Sander et al., 2006) is considered.

${ }^{c}$ Photolysis reactions only considered in the $J_{I_{\mathrm{x}}} \mathrm{O}_{\mathrm{y}}$ scheme. The absorption cross-sections reported in Sect. 2.2 (see Fig. 1) have been used.

Table 3. Iodine chemistry scheme in CAM-Chem: heterogeneous reactions.

\begin{tabular}{ll}
\hline Sea-salt aerosol reactions & Reactive uptake \\
\hline $\mathrm{IONO}_{2} \rightarrow 0.5 \mathrm{IBr}+0.5 \mathrm{ICl}$ & $\gamma=0.01$ \\
$\mathrm{INO}_{2} \rightarrow 0.5 \mathrm{IBr}+0.5 \mathrm{ICl}$ & $\gamma=0.02$ \\
$\mathrm{HOI} \rightarrow 0.5 \mathrm{IBr}+0.5 \mathrm{ICl}$ & $\gamma=0.06$ \\
$\mathrm{I}_{2} \mathrm{O}_{2} \rightarrow$ & $\gamma=0.01^{*}$ \\
$\mathrm{I}_{2} \mathrm{O}_{3} \rightarrow$ & $\gamma=0.01^{*}$ \\
$\mathrm{I}_{2} \mathrm{O}_{4} \rightarrow$ & $\gamma=0.01^{*}$ \\
\hline
\end{tabular}

Values based on the THAMO model (Saiz-Lopez et al., 2008) and implemented in CAM-Chem following Ordóñez et al. (2012).

* Deposition of $\mathrm{I}_{\mathrm{x}} \mathrm{O}_{\mathrm{y}}$ species on sea-salt aerosols has been included following the free regime approximation.

Table 2 presents the photochemical iodine reactions included in CAM-Chem. Absorption cross-sections and quantum yields were compiled from JPL-2010 (Sander et al., 2011) and IUPAC-2008 (Atkinson et al., 2007, 2008), and $J$ values are computed online considering both a look-up table and CAM-Chem actinic flux calculations (Lamarque et al., 2012). Sea-salt heterogeneous recycling reactions for HOI, 
Table 4. Iodine chemistry scheme in CAM-Chem: Henry's Law constants and dry deposition velocities.

\begin{tabular}{llll}
\hline Species & $k_{0}\left(\mathrm{M} \mathrm{atm}^{-1}\right)$ & Deposition velocity* $\left(\mathrm{cm} \mathrm{s}^{-1}\right)$ & Reference \\
\hline $\mathrm{IBr}$ ice & $2.4 \times 10^{1}$ & - & 1 \\
$\mathrm{ICl}$ ice & $1.1 \times 10^{2}$ & - & 1 \\
$\mathrm{HI}$ & $7.8 \times 10^{-1}$ & 1.0 & $1^{\mathrm{a}}$ \\
$\mathrm{HOI}-\left(\mathrm{I}_{\mathrm{I}} \mathrm{O}_{\mathrm{y}} /\right.$ Base $)$ & $1.9 \times 10^{3} / 4.5 \times 10^{3}$ & 0.75 & $1^{\mathrm{b}}$ \\
$\mathrm{IONO} \mathrm{INe}_{2}^{\text {ice }}$ & $1.0 \times 10^{6}$ & 0.75 & $2^{\mathrm{c}}$ \\
$\mathrm{INO}{ }_{2}^{\text {ice }}$ & $3.0 \times 10^{-1}$ & 0.75 & $1^{\mathrm{d}}$ \\
$\mathrm{IO}$ & $4.5 \times 10^{2}$ & - & 2 \\
$\mathrm{OIO}$ & $1.0 \times 10^{4}$ & - & 2 \\
$\mathrm{I}_{2} \mathrm{O}_{2}$ & $1.0 \times 10^{4}$ & 1.0 & 2 \\
$\mathrm{I}_{2} \mathrm{O}_{3}$ & $1.0 \times 10^{4}$ & 1.0 & 2 \\
$\mathrm{I}_{2} \mathrm{O}_{4}$ & $1.0 \times 10^{4}$ & 1.0 & 2 \\
\hline
\end{tabular}

* Dry deposition velocities are based on the THAMO model (Saiz-Lopez et al., 2008).

1 Values reported in Sander (1999).

2 Values based on the THAMO model (Saiz-Lopez et al., 2008).

${ }^{\text {a }}$ Considering a dissociation constant $K_{\mathrm{a}}=3.2 \times 10^{9}$ and a temperature dependent coefficient $c=9800 \mathrm{~K}$

$\mathrm{b}$ Within the range of values given in the corresponding reference.

c Virtually infinite solubility is represented by using a very large arbitrary number.

${ }^{\mathrm{d}}$ Value assumed to be equal to those of $\mathrm{BrNO}_{2}$.

ice Species for which ice-uptake is considered following Neu and Prather (2012).

$\mathrm{INO}_{2}$ and $\mathrm{IONO}_{2}$ are also included in the chemical mechanism (Table 3) following the free regime approximation (McFiggans et al., 2000). Here we consider that the rate-limiting step of the recycling process is the uptake of the gaseous iodine species on the surface of a halogen-enriched (bromide and chloride) aerosol. Note that these recycling reactions constitute a net source of bromine and chlorine to the atmosphere, but represent only a change in partitioning for the case of iodine species. The non-reactive uptake of the higher iodine oxides is also proposed to proceed efficiently on sea-salt aerosols following the free regime approximation, although this additional sink of atmospheric iodine is a minor contributor compared to scavenging of $\mathrm{I}_{\mathrm{x}} \mathrm{O}_{\mathrm{y}}$ in water clouds. Table 4 presents the Henry Law coefficients $\left(k_{\mathrm{H}}\right)$ and deposition velocities used to compute the removal of inorganic iodine from the gaseous phase via washout, scavenging in water and ice clouds, and dry deposition (Neu and Prather, 2012; Ordóñez et al., 2012). The vertical variation of the surface area density (SA) of sea-salt aerosols (SASSLT) and liquid droplets $\left(\mathrm{SA} \mathrm{LIQ}_{\mathrm{L}}\right)$ used to compute the heterogeneous recycling reactions and the wet removal of inorganic iodine, respectively, is described and shown in Fig. 10a of Fernandez et al. (2014).

\subsection{Absorption cross-sections of $\mathrm{I}_{\mathrm{x}} \mathrm{O}_{\mathrm{y}}$}

Prominent featureless absorption bands of $\mathrm{I}_{\mathrm{x}} \mathrm{O}_{\mathrm{y}}$ species have been experimentally observed in the UV region (Bloss et al., 2001; Gómez Martín et al., 2005; Spietz et al., 2005). The photolysis thresholds of the iodine oxides are mostly in the near-infrared region (Gálvez et al., 2013). Therefore, it is plausible that in the atmosphere photochemical decom- position of $\mathrm{I}_{\mathrm{x}} \mathrm{O}_{\mathrm{y}}$ back to $\mathrm{IO}_{\mathrm{x}}$ will compete with thermal decomposition and uptake by aerosol, reducing the atmospheric losses by washout and/or scavenging. Based on the kinetic behaviour of the absorption spectra observed in the laboratory, tentative spectral assignments and estimation of the corresponding absorption cross-section have been reported. While Bloss et al. (2001) assigned the broadband absorption appearing under the IO spectrum to a single species $\left(\mathrm{I}_{2} \mathrm{O}_{2}\right)$, Gómez Martín et al. $(2005,2007)$ obtained evidence of the same band resulting from an overlap of at least two different iodine oxides $\left(\mathrm{I}_{2} \mathrm{O}_{2}\right.$ and $\left.\mathrm{I}_{2} \mathrm{O}_{3}\right)$. Here, in order to calculate atmospheric photolysis rates, we adopt for these two species the spectra extracted and scaled to absolute absorption cross-section by Gómez Martín et al. (2005) (Fig. 1). Extraction of the $\mathrm{I}_{2} \mathrm{O}_{4}$ absorption spectrum from the observed $\mathrm{I}_{\mathrm{x}} \mathrm{O}_{\mathrm{y}}$ broadband absorption was unfeasible, and therefore, in the present work, a solution spectrum measured at the University of Leeds has been used. The $\mathrm{I}_{2} \mathrm{O}_{4}$ spectrum was measured at $1 \mathrm{~nm}$ resolution using a Perkin-Elmer Lambda $900 \mathrm{UV}$-Vis spectrometer in a $1 \mathrm{~cm}$ quartz cuvette (R. Saunders, personal communication, 2012). $\mathrm{I}_{2} \mathrm{O}_{4}$ was synthesized from commercial $\mathrm{I}_{2} \mathrm{O}_{5} / \mathrm{I}_{2}$ and $\mathrm{H}_{2} \mathrm{SO}_{4}$ (Sigma Aldrich). This made iodosyl sulfate, which then, washed, converted to $\mathrm{I}_{2} \mathrm{O}_{4}$ (Daehlie and Kjekshus, 1964). Note that the gas phase absorption spectrum of $\mathrm{I}_{2} \mathrm{O}_{4}$ is likely to be blue-shifted with respect to its spectrum in solution and therefore this may result in overestimation of the atmospheric photolysis rates.

\subsection{Model simulations}

Total inorganic iodine $\left(\mathrm{I}_{\mathrm{y}}\right)$ has been defined as

$\mathrm{I}_{\mathrm{y}}=\mathrm{I}+\mathrm{IO}+\mathrm{HOI}+\mathrm{IONO}_{2}+\mathrm{I}_{\mathrm{x}} \mathrm{O}_{\mathrm{y}}+\mathrm{I}_{\text {minor }}+\mathrm{I}_{\text {dihal }}$, 


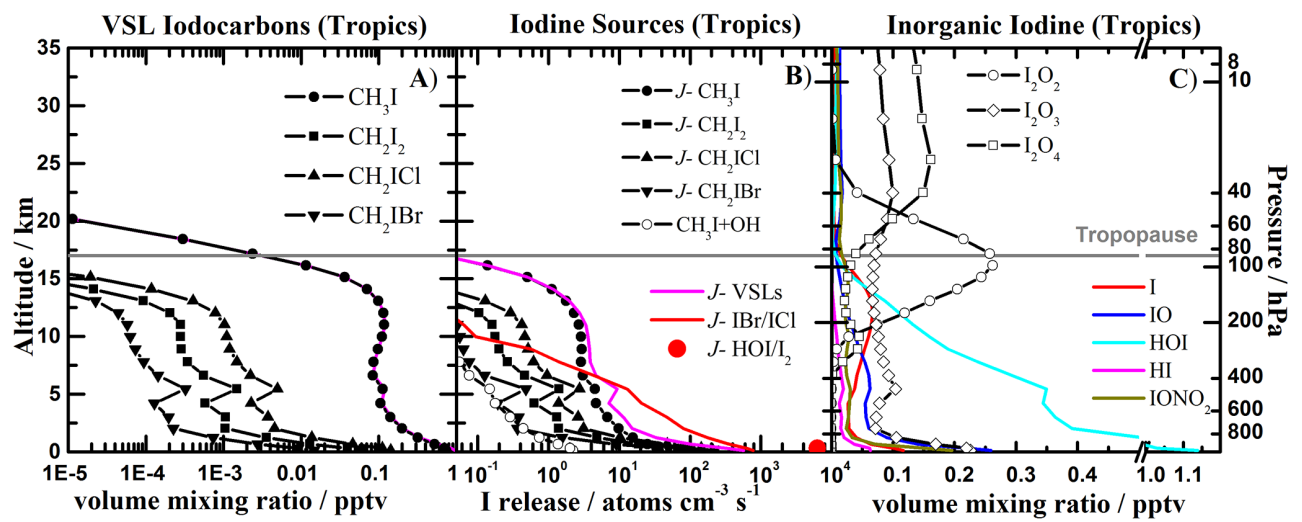

Figure 2. Vertical distributions of annually averaged organic and inorganic iodine species within the tropics (20 N-20 $\mathrm{S})$ : (a) organic VSL iodocarbons; (b) iodine atom released from different sources as a function of altitude; (c) main $\mathrm{I}_{\mathrm{y}}$ species for the Base scheme. The abundance of $\mathrm{I}_{\mathrm{x}} \mathrm{O}_{\mathrm{y}}$ is shown by empty symbols. The horizontal line represents the approximate location of the tropical tropopause. $24 \mathrm{~h}$ average profiles are shown in all cases.

where for simplicity

$\mathrm{I}_{\mathrm{x}} \mathrm{O}_{\mathrm{y}}=2 \times\left(\mathrm{I}_{2} \mathrm{O}_{2}+\mathrm{I}_{2} \mathrm{O}_{3}+\mathrm{I}_{2} \mathrm{O}_{4}\right)$

$\mathrm{I}_{\text {minor }}=\mathrm{HI}+\mathrm{OIO}+\mathrm{INO}_{2}+\mathrm{INO}$

$\mathrm{I}_{\text {dihal }}=2 \times \mathrm{I}_{2}+\mathrm{IBr}+\mathrm{ICl}$.

Two independent simulations were performed in order to estimate the range of $\mathrm{I}_{\mathrm{y}}$ loading and impact in the troposphere: the Base scheme and the $J_{\mathrm{I}_{\mathrm{x}} \mathrm{O}_{\mathrm{y}}}$ scheme. The Base scheme does not consider the photolysis of $\mathrm{I}_{\mathrm{x}} \mathrm{O}_{\mathrm{y}}$ oxides (i.e. $\mathrm{I}_{2} \mathrm{O}_{2}$, $\mathrm{I}_{2} \mathrm{O}_{3}$ and $\mathrm{I}_{2} \mathrm{O}_{4}$ ) and represents the lower $\mathrm{I}_{\mathrm{y}}$ loading limit. In this simulation $\mathrm{I}_{\mathrm{x}} \mathrm{O}_{\mathrm{y}}$ are decomposed back to $\mathrm{IO}_{\mathrm{x}}$ only by thermal decomposition, being removed from the gas phase via washout, uptake on sea-salt aerosols and dry deposition processes. The $J_{\mathrm{I}_{\mathrm{x}} \mathrm{O}_{\mathrm{y}}}$ scheme includes, in addition, the photolysis of $\mathrm{I}_{\mathrm{x}} \mathrm{O}_{\mathrm{y}}$, allowing for an efficient recycling of $\mathrm{IO}_{\mathrm{x}}$ in the gas phase within the troposphere. Therefore this second simulation represents the upper limit of tropospheric $\mathrm{I}_{\mathrm{y}}$ loading. Hereafter we use these two simulations to provide a range of reactive iodine loading, partitioning and distributions throughout the troposphere consistent with our current knowledge of iodine chemistry (within its uncertainties).

\section{Results and discussions}

The upper and lower limits of total inorganic iodine loading in the troposphere have been estimated by conducting simulations where the photolysis of $\mathrm{I}_{\mathrm{x}} \mathrm{O}_{\mathrm{y}}$ was allowed $\left(J_{\mathrm{I}_{\mathrm{x}} \mathrm{O}_{\mathrm{y}}}\right)$ or neglected (Base), respectively. The last of a 3-year simulation was used to compute the iodine atmospheric burden for both cases. As the model is configured with prescribed sea surface temperatures and ice coverage for the 2000 decade (Rayner, 2003), results are not representative of the meteorology of any specific year, and annual averages are presented unless specifically mentioned. Three different vertical regions on consecutive non-overlapping altitude intervals were defined within the tropics $\left(20^{\circ} \mathrm{N}-20^{\circ} \mathrm{S}\right)$ and mid-latitudes $\left(50-20^{\circ} \mathrm{N}\right.$ and $20-50^{\circ} \mathrm{S}$ ): $\mathrm{MBL}$, expanding from the ocean surface up to $\sim 900 \mathrm{~m}$ a.s.l $(\sim 900 \mathrm{hPa})$; the FT, from $\sim 900 \mathrm{~m}(900 \mathrm{hPa})$ to $\sim 8.5 \mathrm{~km}(350 \mathrm{hPa})$; and the UT from $\sim 8.5 \mathrm{~km}(350 \mathrm{hPa})$ up to the model tropopause. Besides the standard $24 \mathrm{~h}$ averaged streaming, time-dependent output for day and night has been generated considering the noon (11:30-12:30) and midnight (23:30-00:30) local time (LT), respectively, for all latitudes and longitudes. Additionally, the Western Pacific (WP) warm pool area was defined by the equator $\left(0^{\circ}\right)$ and the $20^{\circ} \mathrm{N}$ parallels, and the 120 and $165^{\circ} \mathrm{E}$ meridians (see black rectangle in Fig. 7). Gas phase mole fractions for all species are given in ppbv or pptv, which are equivalent to the IUPAC recommended units nmol mol${ }^{-1}$ and pmol mol${ }^{-1}$, respectively (Schwartz and Warneck, 1995).

\subsection{The partitioning of VSL iodine source gases}

Figure 2 shows the vertical profiles of the four major VSL iodocarbons together with their photochemical decomposition rates within the tropics. On an annual average, the total organic iodine abundance results in $\sim 0.8 \mathrm{pptv}$ in the MBL and $\sim 0.1 \mathrm{pptv}$ in the FT (Fig. 2a). The percentage contribution of each individual VSL species to total organic iodine is approximately $82 \%(96 \%), 12 \%(2.7 \%), 5 \%(0.8)$ and $1 \%$ $(0.1 \%)$ for $\mathrm{CH}_{3} \mathrm{I}, \mathrm{CH}_{2} \mathrm{ICl}, \mathrm{CH}_{2} \mathrm{I}_{2}$ and $\mathrm{CH}_{2} \mathrm{IBr}$ in the MBL and (FT), respectively. Iodine-containing di-halocarbons are photolysed almost entirely within the MBL, and the predominant organic species in the free troposphere is methyl iodide. As a consequence, $\mathrm{CH}_{3} \mathrm{I}$ is the only iodocarbon reaching the lower tropical tropopause layer (TTL) by efficient convection; although integrated in the tropics it represents a negligible $\left(\sim 10^{-3}\right.$ pptv) carbon-bonded residual at the coldest point tropopause $\left(\theta_{c p t} \approx 380 \mathrm{~K}\right.$, approx. at $\left.17 \mathrm{~km}\right)$ in agreement with previous studies that determined an inconsiderable 
injection of VSL iodocarbons into the stratosphere (Montzka et al., 2011; Tegtmeier et al., 2013).

Even when the added photodecomposition of $\mathrm{CH}_{2} \mathrm{I}_{2}$, $\mathrm{CH}_{2} \mathrm{IBr}$ and $\mathrm{CH}_{2} \mathrm{ICl}$ within the MBL represents an additional source of inorganic iodine comparable to that of $\mathrm{CH}_{3}$ I (Fig. 2b), several studies have suggested that an additional source of active iodine must exist at the sea surface in order to reconcile open ocean measurements of IO with current knowledge of iodine sources and chemistry (Jones et al., 2010; Mahajan et al., 2010; Gómez Martín et al., 2013b; Großmann et al., 2013). Within CAM-Chem, the inorganic iodine $\left(\mathrm{HOI} / \mathrm{I}_{2}\right)$ released from the tropical oceans following the work of Carpenter et al. (2013) and MacDonald et al. (2014) (see red dot in Fig. $2 \mathrm{~b}, \sim 6.3 \times 10^{3}$ atoms $\mathrm{cm}^{-3} \mathrm{~s}^{-1}$ ) is an order of magnitude higher than that from all organo-iodine species combined $\left(5.7 \times 10^{2}\right.$ atoms $\mathrm{cm}^{-3} \mathrm{~s}^{-1}$ at the surface level and totalling $\sim 1.0 \times 10^{3}$ atoms $\mathrm{cm}^{-3} \mathrm{~s}^{-1}$ in the MBL), and is the dominant source of iodine within the MBL. Another important source of reactive iodine in the lower troposphere is the photolysis of the diatomic $\mathrm{ICl}$ and $\mathrm{IBr}$ species recycled by heterogeneous reactions over sea-salt aerosols (red line in Fig. 2b), which we calculate to be the most important process releasing atomic iodine when integrating the first $5 \mathrm{~km}$ in the marine atmosphere. Note that the implementation of sea-salt recycling in CAM-Chem for iodine species does not constitute a net source of iodine to the troposphere (see Table 3) but represents only a change in iodine partitioning that slows down the conversion of reactive iodine into reservoir species with greater washout efficiencies (i.e. $\mathrm{HOI}$ or $\mathrm{IONO}_{2}$ ). The photolysis of $\mathrm{CH}_{3} \mathrm{I}$ represents 10,60 and $83 \%$ of the total iodine sources from VSL photodecomposition within the MBL, FT and UT respectively, whereas in the lower TTL the source of iodine becomes almost solely $\mathrm{CH}_{3} \mathrm{I}$. The other VSL iodocarbon with a non-negligible contribution to $\mathrm{I}_{\mathrm{y}}$ in the FT and $\mathrm{UT}$ is $\mathrm{CH}_{2} \mathrm{ICl}-$ its $\mathrm{I}$ atom release can reach $22 \%(\mathrm{FT})$, $10 \%$ (UT) and $5 \%$ (TTL) of the total iodine source. Note that from all the VSL species represented in the model $\mathrm{CH}_{2} \mathrm{ICl}$ is the di-halogen iodocarbon with the longest lifetime $(\sim 8 \mathrm{~h})$ and it represents the strongest oceanic VSL source on an iodine atom basis.

The very rapid photolysis of iodocarbons, compared to transport times, makes the relative contribution from each VSL species to the inorganic iodine release to be almost independent of the spatial scale considered. For example, on an annual average, from the total tropical release of atomic iodine at $12 \mathrm{~km} 90 \%$ arise from $\mathrm{CH}_{3} \mathrm{I}$ and $7 \%$ from $\mathrm{CH}_{2} \mathrm{ICl}$, while their respective percentage contributions are 85 and $10 \%$ within the convective WP warm pool during February. This is in contrast to the longer-lived VSL bromocarbons, where the total amount of atomic bromine released from each independent species at a given altitude, within the TTL, strongly depends on the strength of convection (Fernandez et al., 2014). For VSL iodocarbons, the $I_{y}$ loading in the FT and UT depends mainly on the geographical distribution and in- tensity of $\mathrm{CH}_{3} \mathrm{I}$ oceanic emissions, which presents localized areas with stronger fluxes, such as the Indian Ocean and the WP region. Ordóñez et al. (2012) also found that using an emission cycle with non-zero emissions during the night, the monthly average concentrations of $\mathrm{CH}_{2} \mathrm{IX}$ species increase e.g. the iodocarbons, which are the VSL species with shortest lifetimes, can temporally accumulate in the MBL at night and be transported to higher altitudes. This highlights the importance of experimentally determining the shape of the diurnal emission profile to estimate the overall impact of VSL iodocarbons at different heights.

\subsection{Iodine burden in the troposphere and the role of $\mathrm{I}_{\mathbf{x}} \mathrm{O}_{\mathbf{y}}$}

The fast reactions $\mathrm{IO}+\mathrm{IO}, \mathrm{IO}+\mathrm{OIO}$ and $\mathrm{OIO}+\mathrm{OIO}$ lead to the formation of significant levels of $\mathrm{I}_{2} \mathrm{O}_{2}, \mathrm{I}_{2} \mathrm{O}_{3}$ and $\mathrm{I}_{2} \mathrm{O}_{4}$, respectively. As within the Base scheme only thermal decomposition and deposition onto background aerosol of iodine oxides are allowed, the levels of $\mathrm{I}_{\mathrm{x}} \mathrm{O}_{\mathrm{y}}$ build up in the atmosphere, and become the most abundant species in the FT and UT (Fig. 2c). If $\mathrm{I}_{\mathrm{x}} \mathrm{O}_{\mathrm{y}}$ were not photolabile, they would represent $30 \%$ of the total $\mathrm{I}_{\mathrm{y}}$ abundance in the MBL and more than $70 \%$ in the FT and UT. This large mass of iodine in the atmosphere is currently unaccounted for and subject to a large degree of uncertainty about the photochemistry of higher iodine oxides. This presents a fundamental problem in the quantification of iodine chemistry and its effect in the atmosphere, as the particle nucleating $\mathrm{I}_{\mathrm{x}} \mathrm{O}_{\mathrm{y}}$ species do not release active iodine back to the gaseous phase (especially in the FT and UT where temperatures are too low for thermal decomposition to be efficient), representing an effective sink of atmospheric iodine. As many uncertainties still exist on which are the dominant photochemical processes affecting $\mathrm{I}_{\mathrm{x}} \mathrm{O}_{\mathrm{y}}$ species, hereafter, we present our best estimate of the upper and lower range of tropospheric iodine loading and its partitioning for the Base and $J_{\mathrm{I}_{\mathrm{x}} \mathrm{O}_{\mathrm{y}}}$ schemes defined in Sect. 2.3. Most likely, an intermediate mechanism between these two scenarios controls the iodine recycling in the real atmosphere, with a portion of the $\mathrm{I}_{\mathrm{x}} \mathrm{O}_{\mathrm{y}}$ being removed by wet/dry deposition, another one forming larger iodine aggregates which will likely be lost to aerosol, and the rest being recycled to $\mathrm{IO}_{\mathrm{x}}$ in the gas phase by photolysis.

Figure 3 a shows the range of vertical distribution of the main annually averaged daytime iodine species within the tropics $\left(20^{\circ} \mathrm{N}-20^{\circ} \mathrm{S}\right)$ for the Base and $J_{\mathrm{I}_{\mathrm{x}} \mathrm{O}_{\mathrm{y}}}$ schemes. From the surface to about $7-8 \mathrm{~km}$ HOI is the main daytime iodine reservoir. Above that height, atomic iodine becomes the dominant iodine species during the day from the midto upper troposphere, resulting in an averaged $19 \%(58 \%)$ of the total daytime $\mathrm{I}_{\mathrm{y}}$ in the UT for the Base and $\left(J_{\mathrm{I}_{\mathrm{x}} \mathrm{O}_{\mathrm{y}}}\right)$ schemes, respectively. On an annual average, surface daytime IO mixing ratios over the tropical oceans range from 0.45 to $0.7 \mathrm{pptv}$ in agreement with recent ship-borne measurements performed over remote open oceans (Mahajan et 


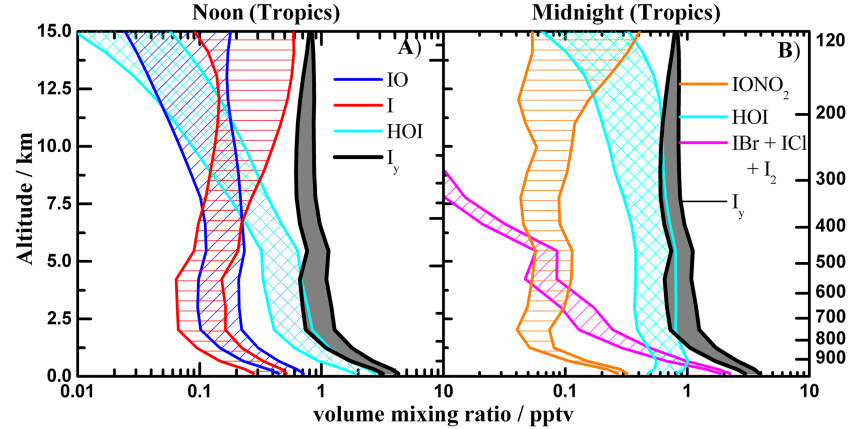

Figure 3. Lower and upper limits of $\mathrm{I}_{\mathrm{y}}$ abundances within the tropical troposphere $\left(20^{\circ} \mathrm{N}-20^{\circ} \mathrm{S}\right)$ : (a) main inorganic species at noon (11:30-12:30 LT); (b) major $\mathrm{I}_{\mathrm{y}}$ species at midnight (23:3000:30 LT). The lower limit corresponds to the Base scheme, while the upper limit is for the $J_{\mathrm{I}_{\mathrm{x}} \mathrm{O}_{\mathrm{y}}}$ scheme.

al., 2012; Großmann et al., 2013). Above the MBL, IO vertical profiles remain in the range $(0.1-0.25)$ pptv between 2 and $8 \mathrm{~km}$, in agreement with recent measurements in the FT performed over the tropical Atlantic (Puentedura et al., 2012) and Pacific (Dix et al., 2013) oceans. The tropospheric IO vertical profiles show two distinct vertical shapes depending on the inclusion or not of the $\mathrm{I}_{\mathrm{x}} \mathrm{O}_{\mathrm{y}}$ photolysis: within the Base scheme there is an evident reduction of IO concentrations with altitude $\left(\mathrm{IO}^{12 \mathrm{~km}}=0.04 \mathrm{pptv}\right)$ due to the large conversion of $\mathrm{IO}_{\mathrm{x}}$ to un-reactive $\mathrm{I}_{\mathrm{x}} \mathrm{O}_{\mathrm{y}}$ in the UT; while for the $J_{\mathrm{I}_{\mathrm{x}} \mathrm{O}_{\mathrm{y}}}$ scheme high levels of IO are maintained throughout the FT and up to the UT $\left(\mathrm{IO}^{12 \mathrm{~km}}=0.16 \mathrm{pptv}\right)$ (see Sect. 3.4). Dix et al. (2013) reported IO vertical profiles over the Pacific Ocean and suggested the existence of an additional process (which they proposed to be heterogeneous sea-salt recycling) in order to sustain the elevated IO levels observed throughout the mid- and upper FT. Our modelling results indicate that heterogeneous recycling on sea-salt can contribute to the IO profile up to about $5 \mathrm{~km}$ (Fig. 2b), however it is very unlikely that reactions on sea-salt can be a source of iodine towards the upper FT, except within convective regions, due to its negligible number concentration at those heights. Instead, we suggest that the combined release of I atoms from $\mathrm{CH}_{3} \mathrm{I}$ photolysis and the photolytic recycling of gaseous $\mathrm{I}_{\mathrm{x}} \mathrm{O}_{\mathrm{y}}$ within the $J_{\mathrm{I}_{\mathrm{x}} \mathrm{O}_{\mathrm{y}}}$ scheme can account for the increase in $\mathrm{IO}_{\mathrm{x}}$ lifetime required to reconcile our current understanding of iodine chemistry to recent field measurements throughout the mid- to upper troposphere (Fig. 3a, see also Sect. 3.4).

The comparative release of reactive iodine species due to $\mathrm{CH}_{3} \mathrm{I}$ photolysis (defined as $\mathrm{d}[\mathrm{I}] / \mathrm{d} t$ ) and that arising from the thermal and photolytic breakdown of $\mathrm{I}_{\mathrm{x}} \mathrm{O}_{\mathrm{y}}$ (defined as $\left.\mathrm{d}\left[\mathrm{IO}_{\mathrm{x}}\right] / \mathrm{d} t=-\mathrm{d}\left[\mathrm{I}_{\mathrm{x}} \mathrm{O}_{\mathrm{y}}\right] / \mathrm{d} t\right)$ is shown in Fig. 4. Note that the losses of higher oxides are equivalent to the production of reactive iodine and do not represent a net sink of iodine in the atmosphere, but a change in partitioning between different $\mathrm{I}_{\mathrm{y}}$ species. Photochemical decomposition of $\mathrm{CH}_{3} \mathrm{I}$
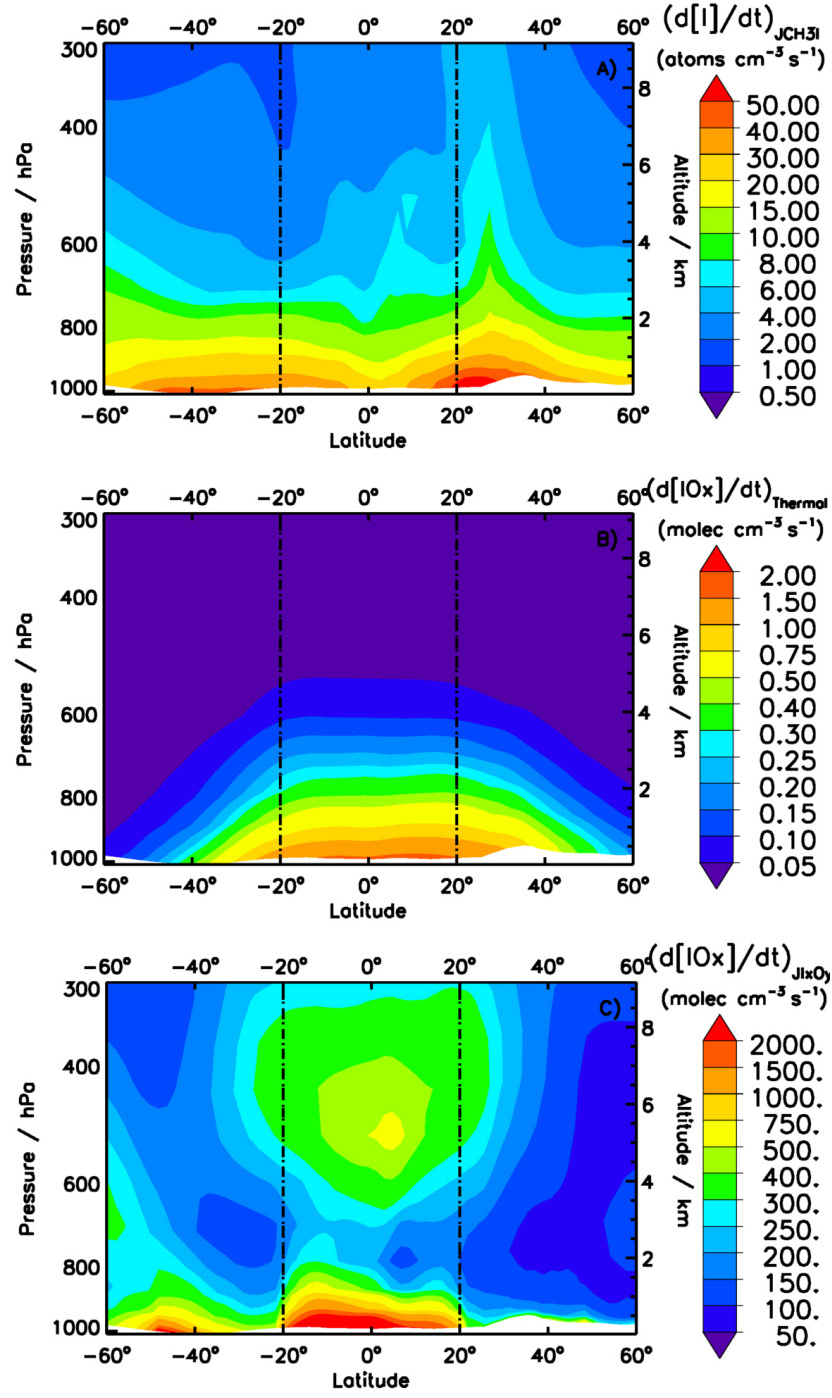

Figure 4. Annual distribution of reactive iodine $\left(\mathrm{IO}_{\mathrm{x}}=\mathrm{I}+\mathrm{IO}\right)$ sources as a function of latitude and altitude: (a) atomic iodine release from photolysis of $\mathrm{CH}_{3} \mathrm{I}$; (b) $\mathrm{IO}_{\mathrm{x}}$ production from thermal decomposition of $\mathrm{I}_{\mathrm{x}} \mathrm{O}_{\mathrm{y}}$ for the Base scheme; (c) photodecomposition of higher oxides within the $J_{\mathrm{I}_{\mathrm{x}} \mathrm{O}_{\mathrm{y}}}$ scheme. Note that for (b) and (c), the photolysis of OIO to I $+\mathrm{O}_{2}$ (Gómez Martín and Plane, 2009) is so efficient that the formation of OIO from $\mathrm{I}_{\mathrm{x}} \mathrm{O}_{\mathrm{y}}$ (Table 1) is computed here as $\mathrm{IO}_{\mathrm{x}} .24 \mathrm{~h}$ averages are shown in all cases.

accounts for up to $50 \mathrm{I}$ atoms $\mathrm{cm}^{-3} \mathrm{~s}^{-1}$, within the MBL, and between 2 and $8 \mathrm{I}$ atoms $\mathrm{cm}^{-3} \mathrm{~s}^{-1}$ in the tropical FT (Fig. 4a). As Base and $J_{\mathrm{I}_{\mathrm{x}} \mathrm{O}_{\mathrm{y}}}$ schemes consider identical VSL sources, the latitudinal distributions are equivalent for both schemes. Within the Base scheme the release of inorganic iodine from VSL sources in the FT is up to three orders of magnitude larger than the contribution from $\mathrm{I}_{\mathrm{x}} \mathrm{O}_{\mathrm{y}}$ thermal decomposition (Fig. 4b), and controls the tropospheric inorganic iodine burden. Due to the slow thermal breakdown of higher oxides, $\mathrm{I}_{\mathrm{x}} \mathrm{O}_{\mathrm{y}}$ accumulate in the FT (Fig. 2c, see also Sect. 3.4). When the photolysis of $\mathrm{I}_{\mathrm{x}} \mathrm{O}_{\mathrm{y}}$ is allowed, this pro- 
cess constitutes the most important source of reactive iodine in the tropical free troposphere, recycling back more than 500 $\mathrm{IO}_{\mathrm{x}}$ molecules $\mathrm{cm}^{-3} \mathrm{~s}^{-1}$, and avoiding a large $\mathrm{I}_{\mathrm{x}} \mathrm{O}_{\mathrm{y}}$ accumulation. As a consequence, larger amounts of $\mathrm{IO}_{\mathrm{x}}$ are maintained at higher altitudes (Fig. 3a). It is worth noting that the photodecomposition of $\mathrm{CH}_{3} \mathrm{I}$ is the first step providing iodine atoms in the FT, and without the contribution from this organic precursor the inorganic iodine loading in the FT and UT would be significantly reduced. Additionally, direct transportation of $\mathrm{I}_{\mathrm{y}}$ species from the MBL, sustained by stoichiometric heterogeneous recycling on sea-salt aerosol, increase the impact of iodine chemistry on the ozone budget as described in Sect. 3.5.

It is worth noting how the crossing-point height for the I-IO $(\sim 7 \mathrm{~km})$, I-HOI $(\sim 9 \mathrm{~km})$ and IO-HOI $(\sim 11 \mathrm{~km})$ vertical noontime profiles occurs at the same altitude, regardless of the consideration or not of the photolysis of the $\mathrm{I}_{\mathrm{x}} \mathrm{O}_{\mathrm{y}}$ (see Fig. 3a). This confirms that the steady state reached is nearly independent of the total amount of $\mathrm{I}_{\mathrm{y}}$ as expected due to the rapid photochemical time constants of the gaseous iodine system. The importance of constraining the absolute $\mathrm{I}_{\mathrm{y}}$ loading in the mid- and upper troposphere is more evident if we consider that the relative oxidative potential of iodine chemistry is greater in the upper troposphere, and that $\sim 80 \%$ of the halogen-mediated tropospheric ozone loss occurs above $800 \mathrm{hPa}$ (Saiz-Lopez et al., 2012b, see Sect. 3.5).

During the night, the main reservoir species in the midand upper troposphere is HOI (Fig. 3b), which accounts for $70 \%$ of the total nighttime $\mathrm{I}_{\mathrm{y}}$ in the FT for the $J_{\mathrm{I}_{\mathrm{x}} \mathrm{O}_{\mathrm{y}}}$ scheme. Therefore, HOI is the most abundant iodine species in the lower troposphere both during the day and at night, and its washout efficiency controls the total atmospheric iodine burden. Indeed, the Henry law constant for $\mathrm{HOI}\left(\mathrm{K}_{\mathrm{H}}^{\mathrm{HOI}}\right)$ has been adjusted between a more (Base) and less $\left(\mathrm{J}_{\mathrm{I}_{\mathrm{x}}} \mathrm{O}_{\mathrm{y}}\right)$ efficient value within the range of measurements and uncertainties reported in the literature (Sander, 1999; see also Table 4). This results in a total washout rate within the tropics in the range of $\sim 6-7 \times 10^{7}$ atoms (I) $\mathrm{cm}^{-2} \mathrm{~s}^{-1}$. For the $J_{\mathrm{I}_{\mathrm{x}}} \mathrm{O}_{\mathrm{y}}$ scheme, $\sim 95 \%$ of the wet-removal occurs in the MBL and FT and is controlled by the uptake on liquid droplets of HOI, $\mathrm{IONO}_{2}$ and $\mathrm{I}_{\mathrm{x}} \mathrm{O}_{\mathrm{y}}(42 \%, 21 \%$ and $16 \%$ respectively). The Base scheme presents a comparatively larger contribution from $\mathrm{I}_{\mathrm{x}} \mathrm{O}_{\mathrm{y}}$ scavenging ( $30 \%$ compared to $12 \%$ for $\mathrm{IONO}_{2}$ ) due to the higher oxide accumulation. Note that from the overall $\mathrm{I}_{\mathrm{x}} \mathrm{O}_{\mathrm{y}}$ sinks, only $\sim 15 \%$ occurs due to irreversible deposition on sea-salt aerosols.

Within the $J_{\mathrm{I}_{\mathrm{x}} \mathrm{O}_{\mathrm{y}}}$ scheme, the $\mathrm{IONO}_{2}$ abundance increases significantly above $10 \mathrm{~km}$, representing the most abundant nighttime inorganic reservoir in the TTL $\left(\mathrm{IONO}_{2}^{15} \mathrm{~km}=0.4 \mathrm{pptv}\right)$ and the main sink of iodine at these heights. In the case of the Base scheme, since less $\mathrm{IO}$ is available (i.e. due to the irreversible conversion of $\mathrm{IO}$ to $\mathrm{I}_{2} \mathrm{O}_{2}$ in the cold UT) for reaction with $\mathrm{NO}_{2}$, the $\mathrm{IONO}_{2}$ levels in the UT are considerably lower (Fig. 3b), and most of the iodine remains in the form of $\mathrm{I}_{\mathrm{x}} \mathrm{O}_{\mathrm{y}}$. This implies that once
$\mathrm{I}_{\mathrm{x}} \mathrm{O}_{\mathrm{y}}$ are formed within the Base scheme, they do not further release active iodine back to the gas phase, and then behave as an unreactive sink of iodine that accumulates in the gas phase. As during daytime, the nocturnal crossing altitude of the $\mathrm{HOI}$ and $\mathrm{IONO}_{2}$ vertical profiles is equivalent for both schemes $(\sim 15 \mathrm{~km})$, indicating that the relative partitioning of the main $\mathrm{I}_{\mathrm{y}}$ species does not depend on the overall $\mathrm{I}_{\mathrm{x}} \mathrm{O}_{\mathrm{y}}$ or total $\mathrm{I}_{\mathrm{y}}$ abundances.

\subsection{The tropical ring of atomic iodine}

Levels of daytime atomic I increase significantly in the middle and upper troposphere due to the low ozone concentrations and temperatures prevailing in these regions, which slow down the formation of IO by the $\mathrm{I}+\mathrm{O}_{3}$ Arrhenius type reaction (Sander et al., 2011). Under these conditions, we simulate a daytime "tropical ring of atomic iodine" with a latitudinal extent from $30^{\circ} \mathrm{N}$ to $30^{\circ} \mathrm{S}$ (Fig. 5). Within this inhomogeneous tropical ring, annual zonal average atomic I peaks at 0.2 and $0.65 \mathrm{pptv}$ for the Base and $J_{\mathrm{I}_{\mathrm{x}} \mathrm{O}_{\mathrm{y}}}$ schemes, respectively, accounting for up to $70 \%$ of the total annually averaged $\mathrm{I}_{\mathrm{y}}$ in the tropics (black contour lines in Fig. 5). The altitude at which the maximum modelled I atom levels are observed depends on the photochemical scheme considered: for the Base scheme the atomic ring extends from 7 to $15 \mathrm{~km}$, peaking at $\sim 11 \mathrm{~km}$ (Fig. 5a-c, top panels), while for the $J_{\mathrm{I}_{\mathrm{x}} \mathrm{O}_{\mathrm{y}}}$ scheme it expands from 8 to $17 \mathrm{~km}$, with maximum abundances located at $\sim 14 \mathrm{~km}$ (Fig. $5 \mathrm{~d}-\mathrm{f}$, bottom). The longitudinal (Fig. 5b, e) and temporal (Fig. 5c, f) variation of the atomic iodine tropical ring suggests that atomic I is globally and annually the most abundant daytime iodine species within the tropics from about $9 \mathrm{~km}$ up to the tropopause. The highest I atom concentrations within the tropical ring are modelled to exist within regions of strong oceanic sources and during periods of strong convection, when large amounts of inorganic iodine are rapidly transported from the MBL to the FT and UT. For example, within the WP region, the monthly I atom abundance peaks at 0.30 and $0.90 \mathrm{pptv}$ for the Base and $J_{\mathrm{I}_{\mathrm{x}}} \mathrm{O}_{\mathrm{y}}$ schemes, respectively.

In both simulated schemes the atomic tropical ring and the relative $\mathrm{I} / \mathrm{I}_{\mathrm{y}}$ distributions are coincident in altitude. Note however that the ultimate fate of the higher iodine oxides in the atmosphere is very uncertain, and within the Base scheme there is an increasing accumulation of $\mathrm{I}_{\mathrm{x}} \mathrm{O}_{\mathrm{y}}$ with altitude. As a consequence, the percentage contribution of atomic iodine to $\mathrm{I}_{\mathrm{y}}$ for the Base scheme is at least halved with respect to the $J_{I_{x}} \mathrm{O}_{\mathrm{y}}$ scheme. If $\mathrm{I}_{\mathrm{x}} \mathrm{O}_{\mathrm{y}}$ species are not considered for the Base scheme, then the I/ $\mathrm{I}_{\mathrm{y}}$ contour lines for both simulations present equivalent values (see Sect. 3.4).

The tropical ring of atomic iodine is a photochemical phenomenon defined by the low abundance of ozone and cold conditions of the upper troposphere. While the absolute ambient levels of iodine species depend on the total inorganic loading of the tropical troposphere (i.e. washout rates, ice-uptake), the unusual feature of the halogen atom being 

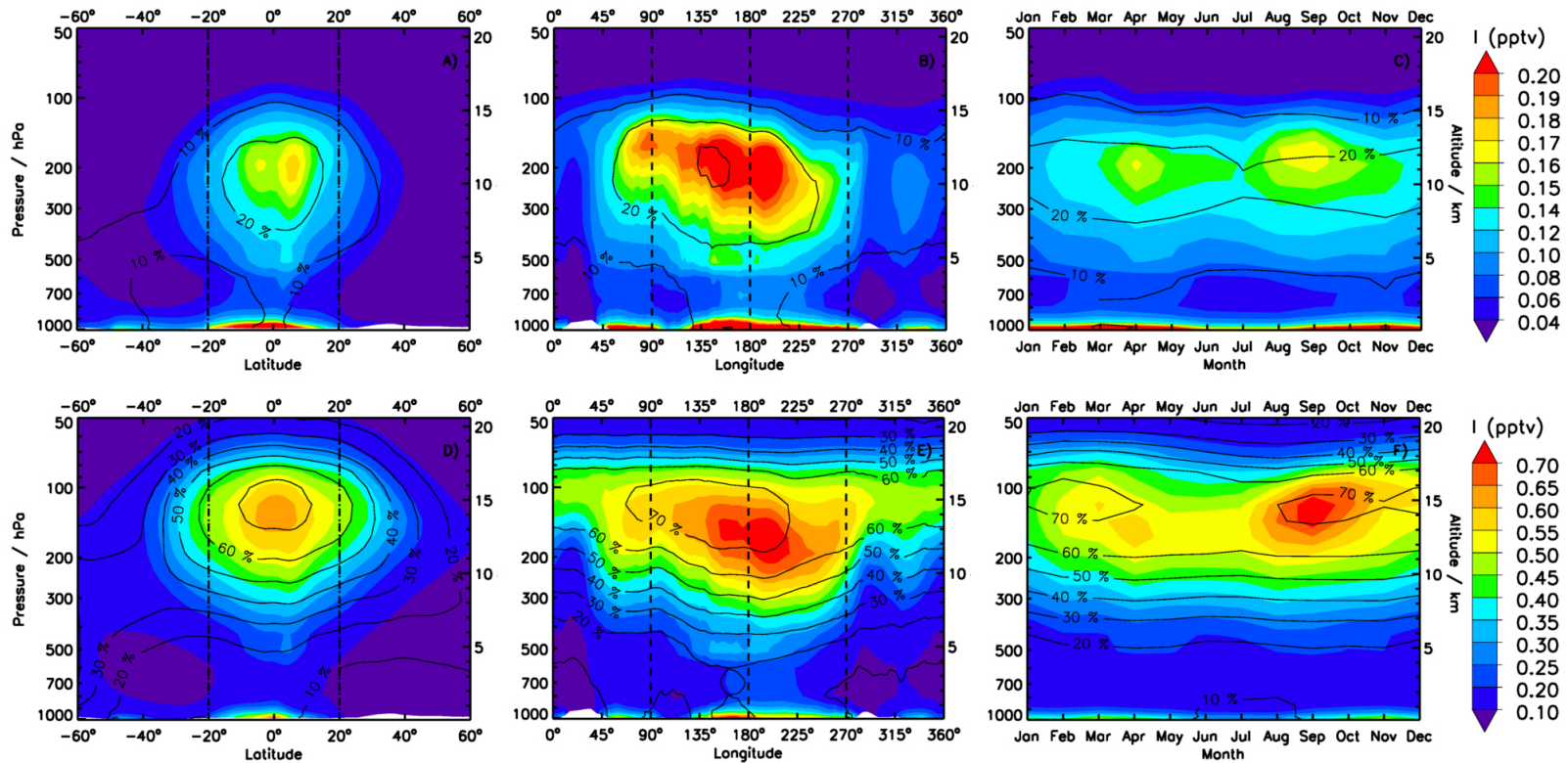

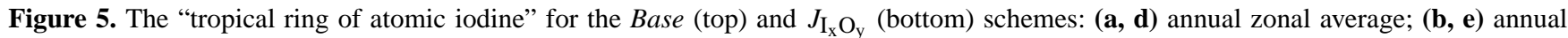
meridional average abundance of atomic I within the tropics $\left(20^{\circ} \mathrm{N}-20^{\circ} \mathrm{S}\right)$; and $(\mathbf{c}, \mathbf{f})$ seasonal evolution of the zonally averaged atomic I ring within the tropics. The colour scale represents noontime volume mixing ratios (pptv) while black contour lines show the percentage contribution of atomic I to $\mathrm{I}_{\mathrm{y}}$.

the predominant species is an implicit consequence of the fast thermal/photochemical interplay within the main iodine chemistry cycling scheme (see Tables 1 and 2) and the natural state of the tropical upper troposphere (i.e. high photolysis rates, lower $\mathrm{O}_{3}$ than in the stratosphere and low temperatures). As the I atom ring is photochemically driven, it is present only in the illuminated portion of the Earth and it circles the tropics with the sun. Fernandez et al. (2014) have suggested a co-existent "tropical ring of atomic bromine" within the TTL. The driving mechanisms of these atomic halogen rings are identical. The distinct features between their relative peak altitude or abundances are due to the different photodissociation rates for $J_{\mathrm{IO}}$ and $J_{\mathrm{BrO}}$, and the different lifetimes of the organic VSL halocarbons that constitute the main source of reactive iodine $\left(\mathrm{CH}_{3} \mathrm{I}\right)$ and bromine $\left(\right.$ mostly $\left.\mathrm{CHBr}_{3}\right)$ in the upper tropical troposphere.

\subsubsection{The I / IO ratio in the troposphere}

As described above, atomic iodine levels surpass IO abundances above $\sim 5-6 \mathrm{~km}$, therefore a ratio I / IO $>1$ must exist in the middle and upper troposphere. Figure 6 a shows the vertical variation of the I/IO ratio for the Base and $J_{I_{\mathrm{x}} \mathrm{O}_{\mathrm{y}}}$ schemes, averaged over different regions and periods within the tropics. A ratio of I IO $>1$ is calculated from the mid-troposphere through the tropical cold point tropopause. Notwithstanding the photochemical treatment of the higher iodine oxides, both schemes present identical I/ IO vertical profiles with maximum values occurring at coincident altitudes $(\sim 14-15 \mathrm{~km}$ or $\sim 130 \mathrm{hPa})$, which indicate that the oc-

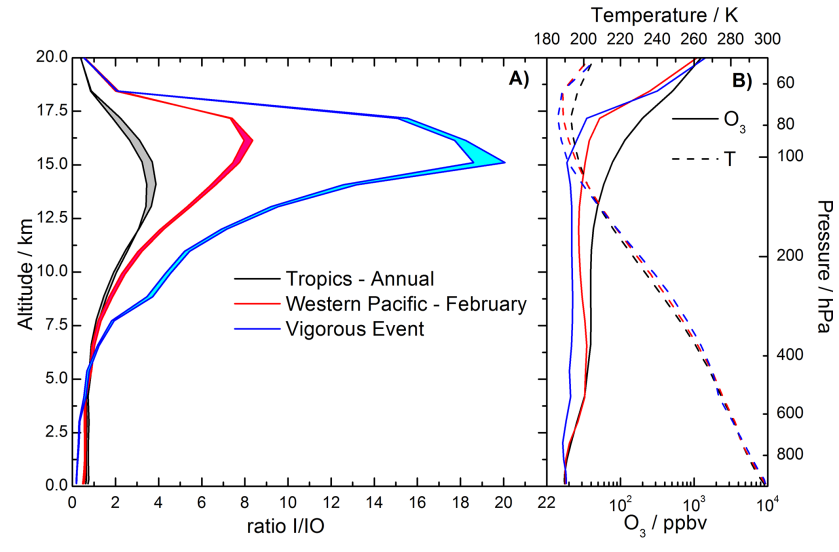

Figure 6. (a) Vertical profiles for the I / IO ratio averaged over different regions and periods of time: (black) annual tropical $\left(20^{\circ} \mathrm{N}-\right.$ $20^{\circ} \mathrm{S}$ ) averages; (red) Western Pacific (WP) warm pool during February; (blue) at the midpoint of a strong convective cell within the WP region during a 3-day period in February. The upper and lower limits correspond to simulations with the Base and $J_{\mathrm{I}_{\mathrm{x}} \mathrm{O}_{\mathrm{y}}}$ schemes, respectively. (b) The vertical variation of $\mathrm{O}_{3}$ abundances and temperature for each region and period of time.

currence of $\mathrm{I} / \mathrm{IO}>1$ is independent of $\mathrm{I}_{\mathrm{y}}$. The peak magnitude strongly depends on the local $\mathrm{O}_{3}$ abundance and the cold temperatures prevailing in the upper troposphere (Fig. 6b). The ratio maximizes during periods and within regions of strong convection, when poor-ozone air-masses are rapidly transported from the lower troposphere to the lower TTL. 

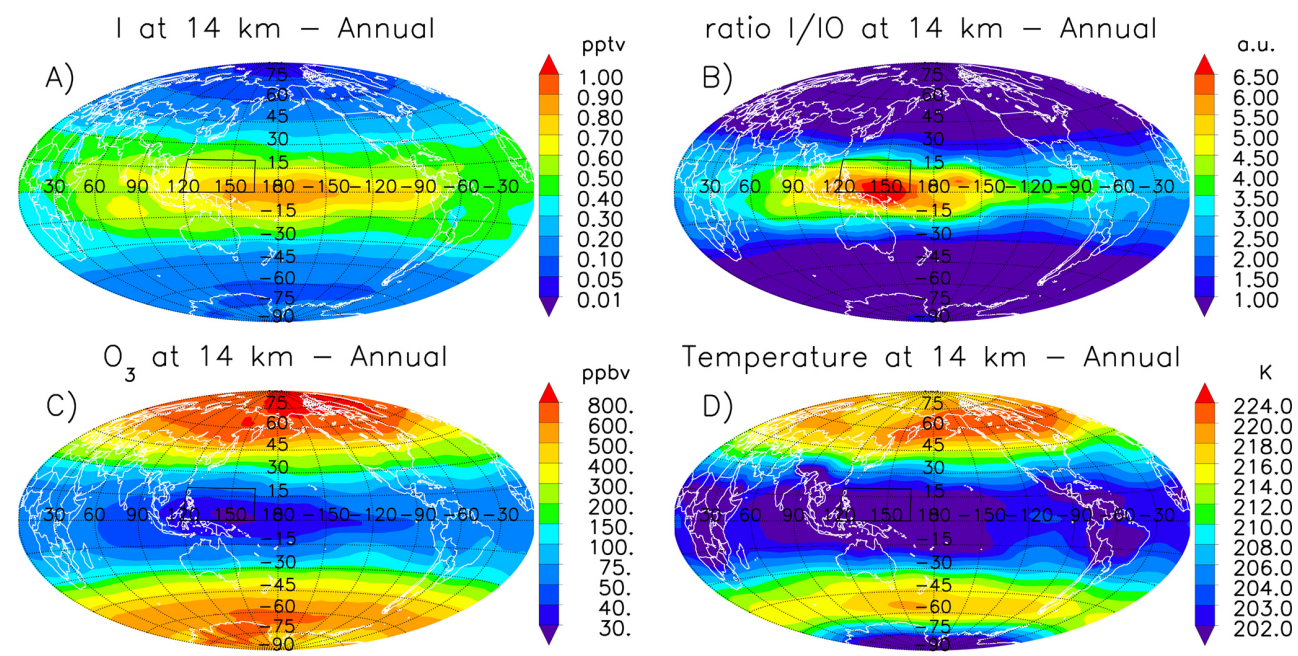

Figure 7. Average annual noontime geographical distribution at $14 \mathrm{~km}$ of: (a) atomic iodine, (b) I / IO ratio, (c) ozone and (d) temperature. The location of the WP region, also considered to compute the vertical profiles of Fig. 6, is outlined by the black rectangle.

Then, both Base and $J_{\mathrm{I}_{\mathrm{x}} \mathrm{O}_{\mathrm{y}}}$ schemes show a ratio enhancement from $\mathrm{I} / \mathrm{IO} \approx 3$ for the tropical annual average to $\sim 8$ within the Western Pacific (WP) warm pool during February. Within the WP region and during a vigorous convective event transporting large amounts of inorganic iodine directly into the lower TTL, the model I / IO ratio reached values as high as $\sim 20$ for both schemes (Fig. 6a). This highlights the importance of measuring atomic iodine levels in the upper troposphere in order to constrain our current knowledge of the iodine burden in this region of the atmosphere.

The $\mathrm{O}_{3}$ concentration and the ambient temperature are the dominant factors in determining the ratio. The ozone levels and surrounding temperatures determining the $\mathrm{I} / \mathrm{IO}>1$ range from 25 to $200 \mathrm{ppbv}$ and from 250 to $190 \mathrm{~K}$ at the lower and higher boundary limit, respectively (Fig. 6b). Following a steady-state approximation considering the two most important reactions involving I and IO species, the ratio can be calculated using the $\mathrm{IO}$ photolysis and the I reaction with $\mathrm{O}_{3}$ :

$$
\frac{[\mathrm{I}]}{[\mathrm{IO}]}=\frac{J_{\mathrm{IO}}}{k_{\mathrm{I}+\mathrm{O}_{3}}\left[\mathrm{O}_{3}\right]}
$$

The contribution from other species that react with atomic I is negligible (see Table 1). Note that even when both schemes result in a similar ratio vertical profile, the $J_{\mathrm{I}_{\mathrm{x}} \mathrm{O}_{\mathrm{y}}}$ scheme calculates slightly smaller ratios because the assumed photochemical breakdown of $\mathrm{I}_{\mathrm{x}} \mathrm{O}_{\mathrm{y}}$ releases $\mathrm{IO}$ radicals back to the gas phase, reducing the I / IO ratio.

The geographical distributions of the tropical ring of atomic iodine and the I/ IO ratio at an altitude of $14 \mathrm{~km}$ are shown in Fig. 7. Results for the $J_{I_{x} \mathrm{O}_{\mathrm{y}}}$ scheme are presented since the maximum values of both the iodine ring and the ratio are coincident in altitude when the photolysis of $\mathrm{I}_{\mathrm{x}} \mathrm{O}_{\mathrm{y}}$ are considered. Both distributions clearly maximize in the Western Pacific region and the Indian Ocean, high- lighting the importance of convective transport and strength of oceanic sources in the occurrence of this natural phenomenon. The I/IO ratio follows the geographical distribution of $\mathrm{O}_{3}$ and temperature, both of which locally minimize in the same region where the ratio peaks (Fig. 7c, d). Note also that I IO > 1 only occurs within the tropical latitudes, decreasing to values smaller than unity polewards of $30^{\circ} \mathrm{N} / 30^{\circ} \mathrm{S}$. Hence, we suggest that experimental programs oriented to reduce the uncertainties of iodine chemistry in the tropical troposphere should also include a strategy for the direct measurements of daytime atomic iodine besides the usually targeted IO radical.

\subsection{The partitioning of inorganic iodine}

Figure 8 shows the $24 \mathrm{~h}$ annual zonal average distribution of the main iodine species (besides atomic iodine) for the Base (left panels) and $J_{\mathrm{I}_{\mathrm{x}}} \mathrm{O}_{\mathrm{y}}$ (right panels) schemes. With the exception of $\mathrm{IONO}_{2}$, which is the only species with a strong hemispheric gradient in the MBL due to the larger anthropogenic $\mathrm{NO}_{\mathrm{x}}$ levels prevailing over the northern oceans, all inorganic iodine species abundances maximize within the tropical regions. IO abundance in the FT is reduced to $\sim 1 / 3$ of its concentration in the MBL, maintaining an approximately constant abundance with height between 2 and $8 \mathrm{~km}$. In the Base scheme, noon IO levels in the tropics $\geq 0.1 \mathrm{pptv}$ between 2 and 7-8 km result from halogen recycling on seasalt (active up to about 4-5 km) and photolysis of $\mathrm{CH}_{3} \mathrm{I}$. Above $7-8 \mathrm{~km}$, and up to the tropopause, noon IO levels $\geq 0.1 \mathrm{pptv}$ can only be sustained by the combined release of iodine atoms from the photodissociation of $\mathrm{CH}_{3} \mathrm{I}$, whose concentration is $\sim 0.1 \mathrm{pptv}$ from 4 to $12 \mathrm{~km}$, and the photolysis of $\mathrm{I}_{\mathrm{x}} \mathrm{O}_{\mathrm{y}}$ that increases the lifetime of $\mathrm{IO}_{\mathrm{x}}$ in the gas phase (see Fig. 4). 

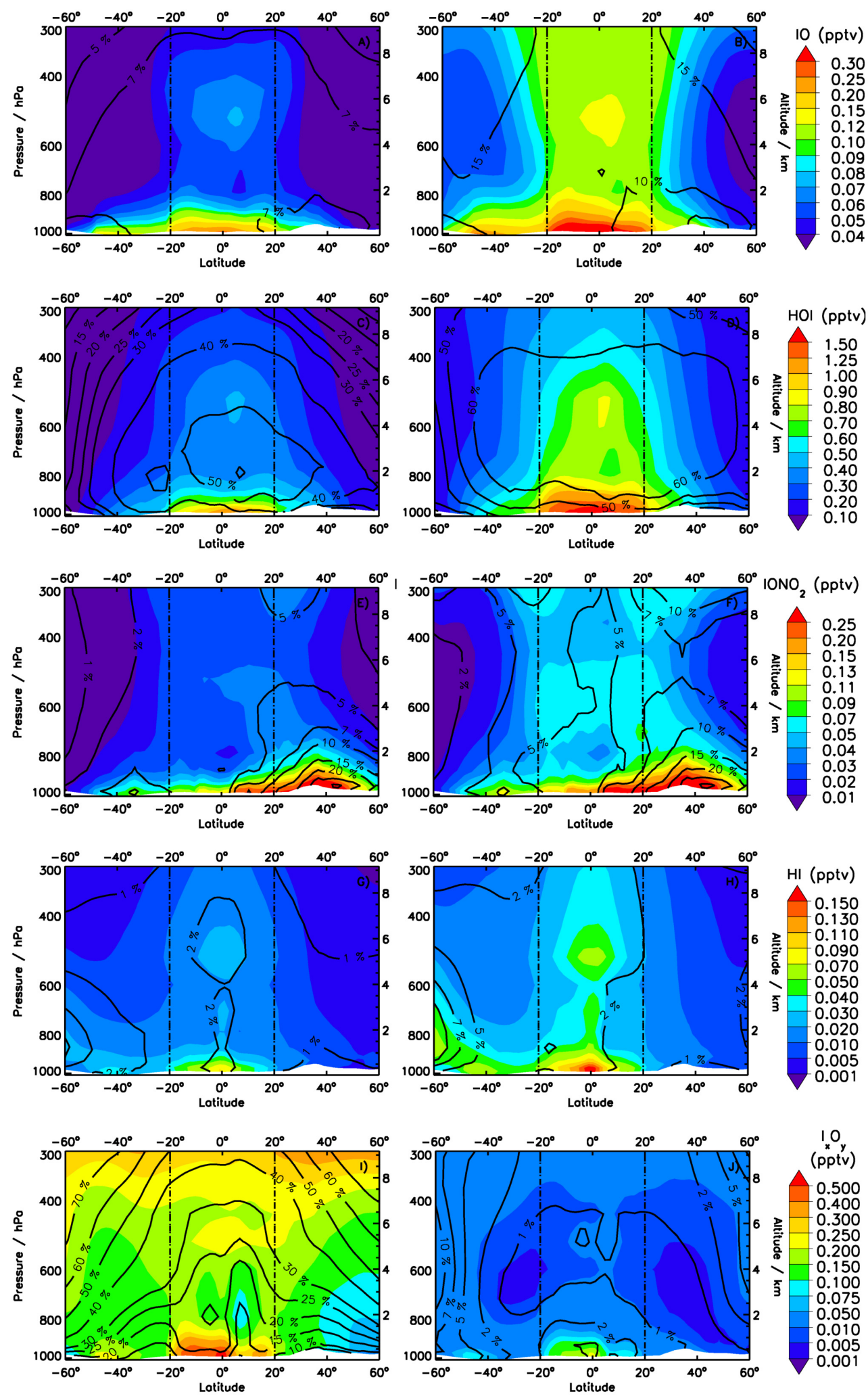

Figure 8. Annual zonal average distribution of the main $\mathrm{I}_{\mathrm{y}}$ species in the troposphere for the Base (left) and $J_{\mathrm{I}_{\mathrm{x}} \mathrm{O}_{\mathrm{y}}}$ (right) schemes. The colour scale represents $24-\mathrm{h}$ average volume mixing ratios (pptv) while black contour lines show the percentage contribution of each species to $\mathrm{I}_{\mathrm{y}}$. 


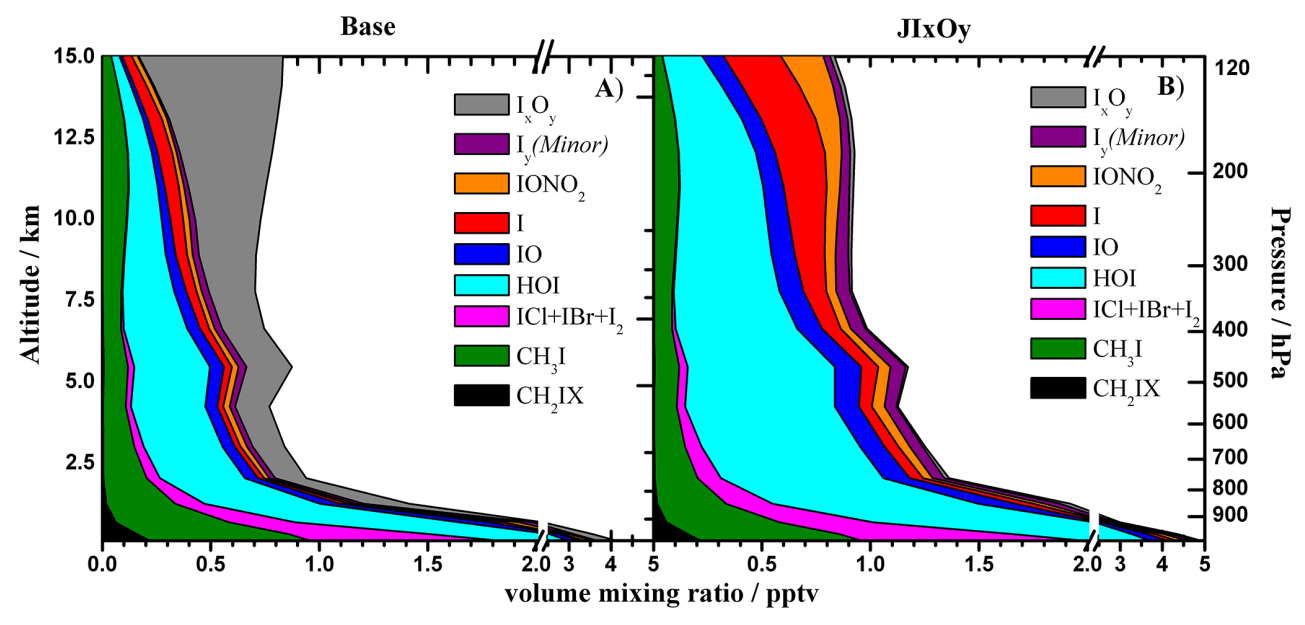

Figure 9. Annual average tropical vertical partitioning of organic and inorganic iodine for the Base (left) and $J_{\mathrm{I}_{\mathrm{x}}} \mathrm{O}_{\mathrm{y}}$ (right) schemes, considering both daytime and nighttime $(24 \mathrm{~h})$ data. Minor organic and inorganic species have been lumped together for simplicity (see text for details).

Figure 8 shows that HOI is the dominant iodine species, representing more than $60 \%$ of total $\mathrm{I}_{\mathrm{y}}$ between 1 and $8 \mathrm{~km}$ for the $J_{\mathrm{I}_{\mathrm{x}}} \mathrm{O}_{\mathrm{y}}$ scheme (HOI is the dominant species both during the day and at night, see Figs. 3 and 11). $\mathrm{HI}$ and $\mathrm{IONO}_{2}$ contributions represent less than $5 \%$ of total $\mathrm{I}_{\mathrm{y}}$ while $\mathrm{IONO}_{2}$ exceeds $10 \%$ in the lower troposphere of the Northern Hemisphere. Note how the abundance of $\mathrm{I}_{\mathrm{x}} \mathrm{O}_{\mathrm{y}}$ increases significantly with altitude for the case of the Base scheme, due to decreasing temperatures that prevent their thermal decomposition (Fig. 8i). This shows that for the Base scheme there is a permanent conversion of the major active iodine species to $\mathrm{I}_{\mathrm{x}} \mathrm{O}_{\mathrm{y}}$, which turns out to be a non-reactive reservoir that does not recycle back to active $\mathrm{IO}_{\mathrm{x}}$ (see grey shading in Fig. 9a). Up to $70 \%$ of the total $\mathrm{I}_{\mathrm{y}}$ is modelled to be transformed to unreactive $\mathrm{I}_{\mathrm{x}} \mathrm{O}_{\mathrm{y}}$ in the upper troposphere within the Base scheme, representing a fundamental problem to our current knowledge of iodine chemistry. Even when the tropospheric washout efficiency of $\mathrm{I}_{\mathrm{x}} \mathrm{O}_{\mathrm{y}}$ is assumed to be larger than that of $\mathrm{HOI}\left(k_{\mathrm{H}}^{\mathrm{I}_{\mathrm{x}} \mathrm{O}_{\mathrm{y}}}>k_{\mathrm{H}}^{\mathrm{HOI}}\right.$, see Table 4$)$, the higher oxides' production is so large, and their thermal decomposition so slow, that their final fate within the Base scheme is to accumulate in the atmosphere. Then, the modelling experiment performed here indicates that either: (i) an unrecognized removal process for $\mathrm{I}_{\mathrm{x}} \mathrm{O}_{\mathrm{y}}$ must exist in the FT and UT, (ii) a substantial accumulation of unreactive $\mathrm{I}_{\mathrm{x}} \mathrm{O}_{\mathrm{y}}$ prevails in the upper troposphere or (iii) a decomposition pathway releasing active iodine, such as the photodecomposition proposed in the $J_{\mathrm{I}_{\mathrm{x}} \mathrm{O}_{\mathrm{y}}}$ scheme, occurs. As to the authors' knowledge there is no evidence for (i) or (ii), we suggest, based on experimental and theoretical studies (i.e. Gómez Martín et al., 2005; SaizLopez et al., 2008) that the photochemistry of $\mathrm{I}_{\mathrm{x}} \mathrm{O}_{\mathrm{y}}$ should be further investigated in order to reduce uncertainties on the important chemical impacts of iodine chemistry. With the assumptions made in the $J_{\mathrm{I}_{\mathrm{x}}} \mathrm{O}_{\mathrm{y}}$ scheme, the $\mathrm{I}_{\mathrm{x}} \mathrm{O}_{\mathrm{y}}$ levels are clearly reduced in favour of other inorganic iodine species (see Fig. 9b), which strongly affect their potential impact on tropospheric ozone destruction (see Sect. 3.5).

Figure 9 shows the vertical variation of the contribution of organic and inorganic species to the total iodine burden within the tropical atmosphere. The only precursor species with a photochemical lifetime long enough to reach the UT is $\mathrm{CH}_{3} \mathrm{I}$, whose abundance remain at $\sim 0.1 \mathrm{pptv}$ until the lower TTL $(\sim 12 \mathrm{~km})$ is reached. There is a small contribution of minor VSL iodocarbons $\left(\mathrm{CH}_{2} \mathrm{I}_{2}, \mathrm{CH}_{2} \mathrm{IBr}\right.$ and $\left.\mathrm{CH}_{2} \mathrm{ICl}\right)$, but most of them are decomposed within the MBL. Note that below $5 \mathrm{~km}$, there is also a non-negligible contribution of dihalogen molecules $\left(\mathrm{ICl}+\mathrm{IBr}+\mathrm{I}_{2}\right)$, which on average for the whole year, represent up to $0.25-0.30 \mathrm{pptv}$ of $\mathrm{I}_{\mathrm{y}}$ integrated within the tropical MBL. At the ocean surface, the modelled overall abundance of $\mathrm{I}_{2}, \mathrm{ICl}$ and $\mathrm{IBr}$ species at nighttime reaches 1.3 (1.7) pptv for the Base $\left(J_{\mathrm{I}_{\mathrm{x}} \mathrm{O}_{\mathrm{y}}}\right)$ schemes, respectively (Fig. 3b). The predominant contribution of these diatomic species to nighttime $\mathrm{I}_{\mathrm{y}}$ decreases rapidly with altitude due to the rapid reduction in the availability of sea-salt aerosol surface, upon which $\mathrm{IBr}$ and $\mathrm{ICl}$ are formed following the uptake and heterogeneous recycling of $\mathrm{IONO}_{2}, \mathrm{INO}_{2}$ and HOI (see Table 3). Additionally, an abiotic source of $\mathrm{I}_{2}$ (as well as HOI) is introduced in the model at the ocean surface following the oxidative reaction of ozone with aqueous iodide (see Sect. 2.1). Within the tropics, approximately half of this inorganic oceanic flux is released during the night, resulting in the direct buildup of $\mathrm{I}_{2}$ in the lower atmosphere, as well as an indirect buildup of $\mathrm{ICl}$ and $\mathrm{IBr}$ due to the heterogeneous recycling of $\mathrm{HOI}$ on sea-salt aerosols. Up to $50 \%$ of the nighttime $\mathrm{I}_{\mathrm{y}}$ within the MBL is in the form of $\mathrm{I}_{2}+\mathrm{IBr}+\mathrm{ICl}$. The relative contribution of $\mathrm{I}_{2}, \mathrm{IBr}$ and $\mathrm{ICl}$ to the overall di-halogen contributions within the MBL are, respectively, 68, 16 and $16 \%$ for the Base scheme, and 53, 23 and $23 \%$ for the $J_{I_{x} O_{y}}$ scheme. Note that the contribution of 

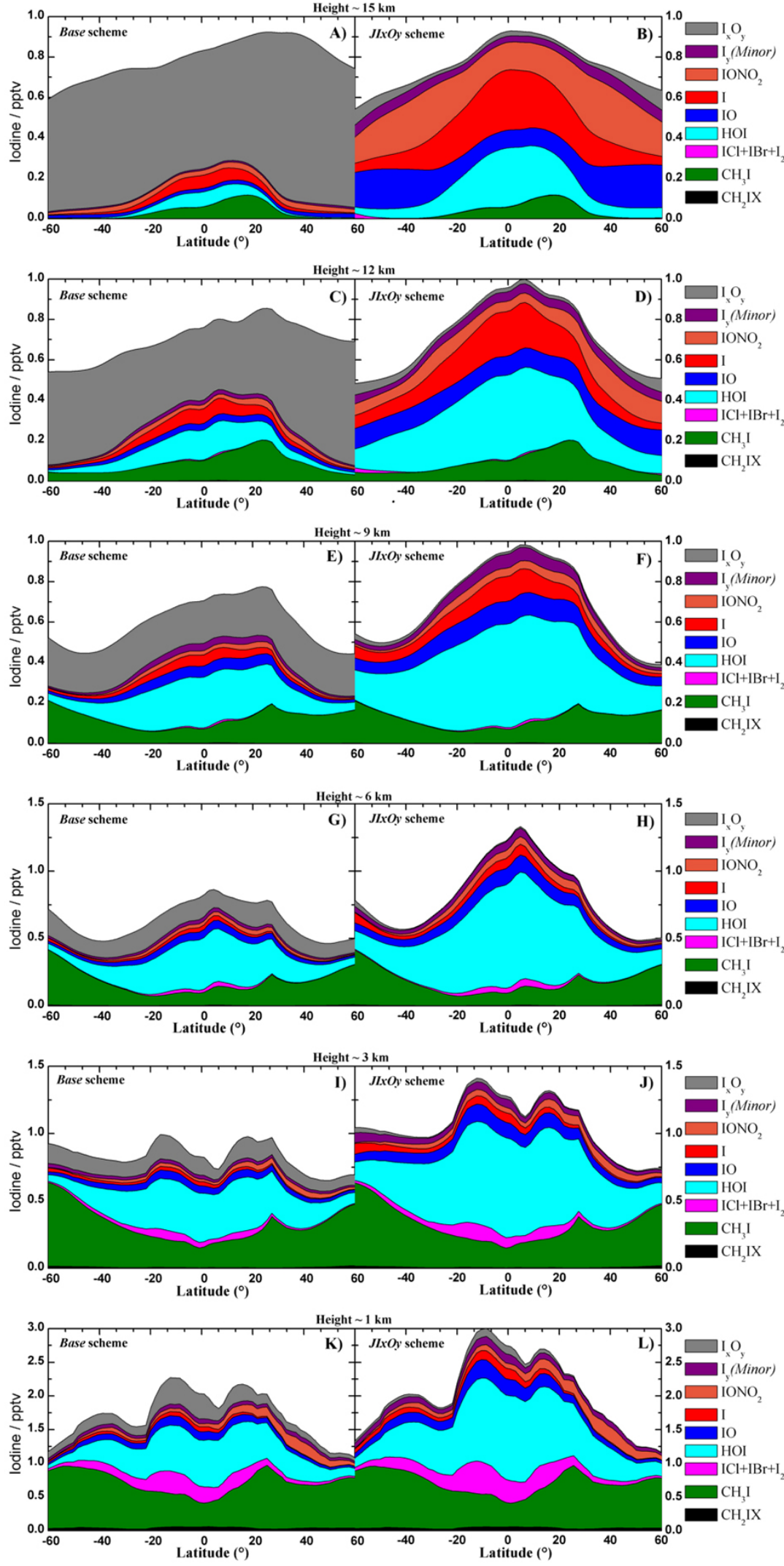

Figure 10. Zonal additive distribution of main organic and inorganic iodine species at different altitudes for the Base (left) and $J_{\mathrm{I}_{\mathrm{x}}} \mathrm{O}_{\mathrm{y}}$ (right) schemes. $24 \mathrm{~h}$ average volume mixing ratios (pptv) are presented at approximate heights of 1, 3, 6, 9, 12 and $15 \mathrm{~km}$. Minor organic and inorganic species have been lumped together for simplicity (see text for details). 

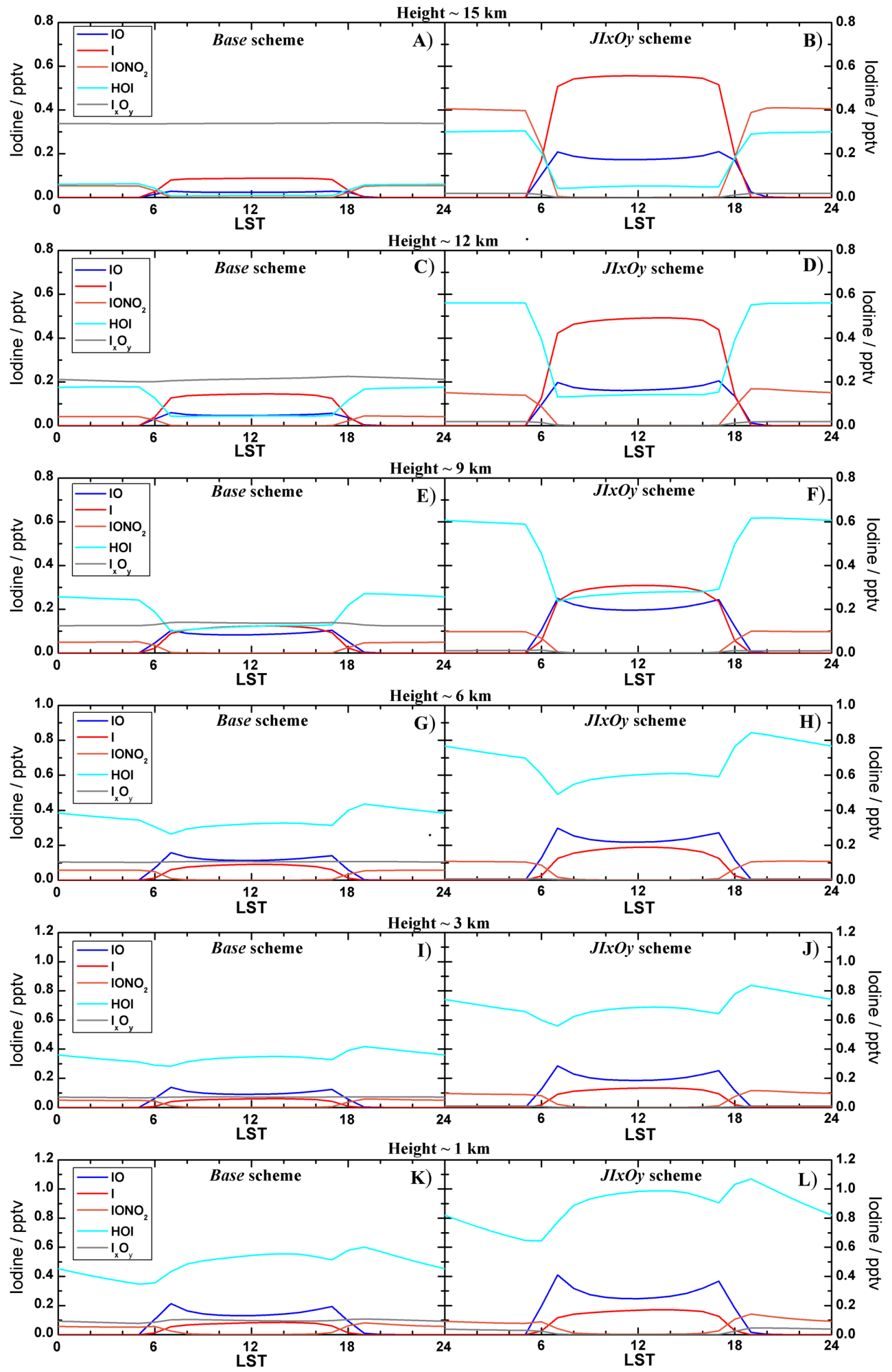

Figure 11. Diurnal variation of main inorganic iodine species at different altitudes for the Base (left) and $J_{\mathrm{I}_{\mathrm{x}} \mathrm{O}_{\mathrm{y}}}$ (right) schemes. Tropical averages considering locations with equivalent local times have been computed. Results are shown at approximate heights of $1,3,6,9,12$ and $15 \mathrm{~km}$ 
the minor iodine species $\left(\mathrm{I}_{\text {minor }}\right)$ represents less than $5 \%$ of $\mathrm{I}_{\mathrm{y}}$ in both schemes.

Compared to the organic portion, the inorganic fraction is the dominant component of the total iodine budget for both schemes, with $\mathrm{I}_{\mathrm{y}}$ representing more than $90 \%$ of total iodine through the mid- to upper troposphere (Fig. 9). This is in clear contrast to the bromine partitioning in the troposphere where, even if the abundant long-lived halons and $\mathrm{CH}_{3} \mathrm{Br}$ are left aside and just VSL bromocarbons are considered, only $30-40 \%$ of bromine is inorganic in the FT, with the dominant component being the organic VSL portion (Fernandez et al., 2014).

Figure 10 shows the annual additive zonal distribution of iodine species. Results are presented at selected heights of around 1, 3, 6, 9, 12 and $15 \mathrm{~km}$ for the Base (left panels) and the $J_{\mathrm{I}_{\mathrm{x}} \mathrm{O}_{\mathrm{y}}}$ (right panels) schemes. The rapid conversion of organic VSL iodocarbons (mainly $\mathrm{CH}_{3} \mathrm{I}$ ) to inorganic iodine as the altitude increases (and across latitudes) as well as the above-mentioned accumulation of $\mathrm{I}_{\mathrm{x}} \mathrm{O}_{\mathrm{y}}$ in the Base scheme, are clearly appreciated in Fig. 10. Note that even when the total inorganic loading for the $J_{\mathrm{I}_{\mathrm{x}}} \mathrm{O}_{\mathrm{y}}$ scheme is only 10-20\% larger than for the Base scheme, the absolute abundance of the main $\mathrm{I}_{\mathrm{y}}$ species (HOI, I and IO) can be up to a factor of $\sim 5$ greater when $\mathrm{I}_{\mathrm{x}} \mathrm{O}_{\mathrm{y}}$ are photolysed. Indeed, if $\mathrm{I}_{\mathrm{x}} \mathrm{O}_{\mathrm{y}}$ are not considered when computing the total inorganic iodine (i.e. defining an equivalent magnitude $\mathrm{I}_{\mathrm{y}}^{*}=\mathrm{I}_{\mathrm{y}}-\mathrm{I}_{\mathrm{x}} \mathrm{O}_{\mathrm{y}}$ ), then the relative contributions $\mathrm{I} / \mathrm{I}_{\mathrm{y}}^{*}, \mathrm{IO} / \mathrm{I}_{\mathrm{y}}^{*}$ and $\mathrm{HOI} / \mathrm{I}_{\mathrm{y}}^{*}$ for the Base scheme are equivalent to I / $\mathrm{I}_{\mathrm{y}}, \mathrm{IO} / \mathrm{I}_{\mathrm{y}}$ and HOI $/ \mathrm{I}_{\mathrm{y}}$ for the $J_{\mathrm{I}_{\mathrm{x}} \mathrm{O}_{\mathrm{y}}}$ scheme. This confirms the rapid establishment of the photochemical steady state for the gaseous iodine system and the inert role of $\mathrm{I}_{\mathrm{x}} \mathrm{O}_{\mathrm{y}}$ on altering the $\mathrm{I}_{\mathrm{y}}$ partitioning for the Base scheme, thereby indicating that $\mathrm{I}_{\mathrm{x}} \mathrm{O}_{\mathrm{y}}$ production could basically be treated as an efficient sink of inorganic iodine, unless their photodissociation is considered.

For the same heights as Fig. 10, the average diurnal variation of the main iodine species is illustrated in Fig. 11. In the tropics, I and IO follow a diurnal concentration profile with a characteristic top-hat shape due to the fast photochemical constants of the iodine system which allows the rapid occurrence of the I-IO steady state. Note that the diurnal top-hat shape of IO is also influenced by the daytime loss of IO by reaction with $\mathrm{HO}_{2}$. IO is the dominant daytime species below $5 \mathrm{~km}$, while atomic iodine dominates above that height, defining the diurnal temporal evolution of the tropical I ring. IO levels show a double peak at dawn and dusk, which is most evident at lower altitudes. This is attributed to the reduced photodissociation of the IO radical during sunrise and sunset, particularly at lower heights, which favours the displacement of the steady state towards IO. During daylight hours, both I and IO abundances remain almost constant with time, while at nighttime they are completely converted to the reservoir species $\mathrm{HOI}$ and $\mathrm{IONO}_{2}$. The balance between the nighttime reservoirs species is shifted from the predominance of HOI in the low- to mid-troposphere to that of $\mathrm{IONO}_{2}$ in the UT, following the increase in $\mathrm{NO}_{2}$ concen- trations towards the upper troposphere. Overall, the diurnal variation of inorganic iodine shown here for the tropical upper troposphere, with elevated levels of I and IO at daytime and conversion to $\mathrm{HOI}$ and $\mathrm{IONO}_{2}$ at nighttime, is in line with previous photochemical calculations of iodine in the tropical UT (Butz et al., 2009). Note that in the Base scheme $\mathrm{I}_{\mathrm{x}} \mathrm{O}_{\mathrm{y}}$ shows a flat diurnal concentration profile whereas in the $J_{\mathrm{I}_{\mathrm{x}} \mathrm{O}_{\mathrm{y}}}$ scheme the $\mathrm{I}_{\mathrm{x}} \mathrm{O}_{\mathrm{y}}$ daytime concentrations are negligible, due to efficient photolysis, and are only above pptv levels at night although at much lower abundances than $\mathrm{IONO}_{2}$ and HOI. In both schemes the HOI photolysis dominates the early morning release of I atoms, compared to $\mathrm{IONO}_{2}$, as evidenced by the faster decrease of HOI throughout sunrise (Fig. 11); this difference becomes smaller with altitude. This is due to the absorption spectrum of HOI in the visible as opposed to the strong absorption cross-section of $\mathrm{IONO}_{2}$ in the ultraviolet (below 300nm) (Saiz-Lopez et al., 2012a). During the daytime, HOI is the main species up to about $6 \mathrm{~km}$; at higher altitudes in the troposphere the accumulation of $\mathrm{I}_{\mathrm{x}} \mathrm{O}_{\mathrm{y}}$ in the Base scheme and the very rapid interplay between I and IO in the $J_{\mathrm{I}_{\mathrm{x}} \mathrm{O}_{\mathrm{y}}}$ scheme dominate daytime $\mathrm{I}_{\mathrm{y}}$.

\subsection{Implications for tropospheric ozone}

Figure 12 presents the annual tropospheric ozone difference between the Base and $J_{\mathrm{I}_{\mathrm{x}} \mathrm{O}_{\mathrm{y}}}$ schemes as a function of altitude and latitude. The $\mathrm{O}_{3}$ changes increase from $\sim 0.5 \mathrm{ppbv}$ in the tropical MBL to up to $\sim 2.5 \mathrm{ppbv}$ in the UT of the midlatitudes (Fig. 12b) following the increase of $\mathrm{O}_{3}$ abundances as the latitude and altitude increase (Fig. 12a). The ozone differences show a pronounced hemispheric dependence, with greater percentage changes (with respect to the Base scheme) of 5-6\% for the SH due to the reduced impact of anthropogenic $\mathrm{O}_{3}$ precursors, as compared to the $\mathrm{NH}$. The $\left(J_{\mathrm{I}_{\mathrm{x}} \mathrm{O}_{\mathrm{y}}}-\right.$ Base) differences shown in Fig. 12b are of the same magnitude as those found between a pair of non-iodine simulations including $(\mathrm{OnlyBr})$ and neglecting the bromine contributions from VSL bromocarbons (NoVSL). This suggests that the uncertainties on the impact of iodine chemistry on the ozone budget (i.e. uncertainties in the photochemistry of $\mathrm{I}_{\mathrm{x}} \mathrm{O}_{\mathrm{y}}$ ) are of the same magnitude as the overall impact of tropospheric bromine chemistry from VSLs (OnlyBr - NoVSL, Fig, 12d). Indeed, even when the lower atmospheric iodine loading is considered (Base - OnlyBr, Fig. 12c) the impact on tropospheric ozone at $\sim 5 \mathrm{~km}(400-500 \mathrm{hPa})$ is equivalent to that obtained when only bromine chemistry is considered. This all highlights the need for further experimental research on the photochemical characterization of $\mathrm{I}_{\mathrm{x}} \mathrm{O}_{\mathrm{y}}$.

Figure 13 presents the absolute (Fig. 13a) and relative (Fig. 13b) vertical range of ozone loss rate between the Base and $J_{\mathrm{I}_{\mathrm{x}} \mathrm{O}_{\mathrm{y}}}$ schemes for each chemical family that participates in tropospheric odd oxygen $\left(\mathrm{O}_{\mathrm{x}}\right)$ loss cycles. The $\mathrm{O}_{\mathrm{x}}$ loss rates equations for the ozone-depleting families considered in this work are presented in Table 5. The formalism used here is based on the catalytic cycles and chemical fam- 
Table 5. Odd oxygen $\left(\mathrm{O}_{\mathrm{x}}\right)$ loss rates reactions grouped by family cycles.

\begin{tabular}{|c|c|c|c|}
\hline Family & Reaction & $\Delta \mathrm{O}_{\mathrm{x}}$ & Odd oxygen loss ${ }^{1}$ \\
\hline $\mathrm{O}_{\mathrm{x}}$ & $\begin{array}{l}\mathrm{O}+\mathrm{O}_{3} \rightarrow 2 \times \mathrm{O}_{2} \\
\mathrm{O}(1 \mathrm{D})+\mathrm{H}_{2} \mathrm{O} \rightarrow 2 \times \mathrm{OH}\end{array}$ & $\begin{array}{l}-2 \\
-1\end{array}$ & $\mathrm{O}_{\mathrm{x} \text { Loss }}=2 \times R_{\mathrm{O}+\mathrm{O}_{3}}+R_{\mathrm{O} 1 \mathrm{D}+\mathrm{H}_{2} \mathrm{O}}$ \\
\hline $\mathrm{HO}_{\mathrm{x}}$ & $\begin{array}{l}\mathrm{HO}_{2}+\mathrm{O} \rightarrow \mathrm{OH}+\mathrm{O}_{2} \\
\mathrm{HO}_{2}+\mathrm{O}_{3} \rightarrow \mathrm{OH}+2 \times \mathrm{O}_{2}\end{array}$ & $\begin{array}{l}-2^{2} \\
-2^{2}\end{array}$ & $\mathrm{HO}_{\mathrm{x} \text { Loss }}=2 \times\left(R_{\mathrm{HO}_{2}+\mathrm{O}}+R_{\mathrm{HO}_{2}+\mathrm{O}_{3}}\right)$ \\
\hline $\mathrm{NO}_{\mathrm{x}}$ & $\begin{array}{l}\mathrm{NO}_{2}+\mathrm{O} \rightarrow \mathrm{NO}+\mathrm{O}_{2} \\
\mathrm{NO}_{3}+h v \rightarrow \mathrm{NO}+\mathrm{O}_{2}\end{array}$ & $\begin{array}{l}-2 \\
-2\end{array}$ & $\mathrm{NO}_{\mathrm{x} \text { Loss }}=2 \times\left(R_{\mathrm{NO}_{2}+\mathrm{O}}+J_{\mathrm{NO}_{3}}\right)$ \\
\hline \multirow[t]{3}{*}{$\mathrm{BrO}_{\mathrm{x}}+\mathrm{ClO}_{\mathrm{x}}$} & $\begin{array}{l}\mathrm{ClO}+\mathrm{O} \rightarrow \mathrm{Cl}+\mathrm{O}_{2} \\
\mathrm{Cl}_{2} \mathrm{O}_{2}+h v \rightarrow 2 \times \mathrm{Cl}+\mathrm{O}_{2} \\
\mathrm{ClO}+\mathrm{HO}_{2} \rightarrow \mathrm{HOCl}+\mathrm{O}_{2}\end{array}$ & $\begin{array}{l}-2 \\
-2 \\
-2^{3} \\
\end{array}$ & $\begin{array}{l}\mathrm{BrO}_{\mathrm{x}}-\mathrm{ClO}_{\mathrm{x} \mathrm{Loss}}=2 \times\left(R_{\mathrm{ClO}+\mathrm{O}}+J_{\mathrm{Cl}_{2} \mathrm{O}_{2}}\right. \\
\left.+R_{\mathrm{ClO}+\mathrm{HO}_{2}}\right)\end{array}$ \\
\hline & $\begin{array}{l}\mathrm{BrO}+\mathrm{O} \rightarrow \mathrm{Br}+\mathrm{O}_{2} \\
\mathrm{BrO}+\mathrm{HO}_{2} \rightarrow \mathrm{HOBr}+\mathrm{O}_{2}\end{array}$ & $\begin{array}{l}-2 \\
-2^{3} \\
\end{array}$ & $+2 \times\left(R_{\mathrm{BrO}+\mathrm{O}}+\mathrm{R}_{\mathrm{BrO}+\mathrm{HO}_{2}}\right)$ \\
\hline & $\begin{array}{l}\mathrm{BrO}+\mathrm{ClO} \rightarrow \mathrm{Br}+\mathrm{Cl}+\mathrm{O}_{2} \\
\mathrm{BrO}+\mathrm{ClO} \rightarrow \mathrm{BrCl}+\mathrm{O}_{2}\end{array}$ & $\begin{array}{l}-2 \\
-2\end{array}$ & $+2 \times\left(R_{\mathrm{BrO}+\mathrm{ClO}}^{\mathrm{b}}+R_{\mathrm{BrO}+\mathrm{ClO}}^{\mathrm{c}}\right)$ \\
\hline \multirow[t]{2}{*}{$\mathrm{IO}_{\mathrm{x}}$} & $\begin{array}{l}\mathrm{IO}+\mathrm{O} \rightarrow \mathrm{I}+\mathrm{O}_{2} \\
\mathrm{OIO}+h v \rightarrow \mathrm{I}+\mathrm{O}_{2} \\
\mathrm{IO}+\mathrm{HO}_{2} \rightarrow \mathrm{HOI}+\mathrm{O}_{2}\end{array}$ & $\begin{array}{l}-2 \\
-2 \\
-2^{3} \\
\end{array}$ & $\mathrm{IO}_{\mathrm{x} \text { Loss }}=2 \times\left(R_{\mathrm{IO}+\mathrm{O}}+J_{\mathrm{OIO}}+R_{\mathrm{IO}+\mathrm{HO}_{2}}\right)$ \\
\hline & $\begin{array}{l}\mathrm{IO}+\mathrm{BrO} \rightarrow \mathrm{I}+\mathrm{Br}+\mathrm{O}_{2} \\
\mathrm{IO}+\mathrm{ClO} \rightarrow \mathrm{I}+\mathrm{Cl}+\mathrm{O}_{2} \\
\mathrm{IO}+\mathrm{ClO} \rightarrow \mathrm{ICl}+\mathrm{O}_{2}\end{array}$ & $\begin{array}{l}-2 \\
-2 \\
-2\end{array}$ & $+2 \times\left(R_{\mathrm{IO}+\mathrm{BrO}}^{\mathrm{a}}+R_{\mathrm{IO}+\mathrm{ClO}}^{\mathrm{b}}+R_{\mathrm{IO}+\mathrm{ClO}}^{\mathrm{c}}\right)$ \\
\hline
\end{tabular}

$\mathrm{O}_{\mathrm{x}}=\mathrm{O}\left({ }^{3} \mathrm{P}\right)+\mathrm{O}\left({ }^{1} \mathrm{D}\right)+\mathrm{O}_{3}+\mathrm{NO}_{2}+2 \times \mathrm{NO}_{3}+\mathrm{HNO}_{3}+\mathrm{HO}_{2} \mathrm{NO}_{2}+2 \times \mathrm{N}_{2} \mathrm{O}_{5}+\mathrm{ClO}+2 \times \mathrm{Cl}_{2} \mathrm{O}_{2}+2 \times \mathrm{OClO}+2 \times \mathrm{ClONO}_{2}+$ $\mathrm{BrO}+2 \times \mathrm{BrONO}_{2}+\mathrm{IO}+2 \times \mathrm{OIO}+2 \times \mathrm{IONO}_{2}+2 \times \mathrm{I}_{2} \mathrm{O}_{2}+3 \times \mathrm{I}_{2} \mathrm{O}_{3}+4 \times \mathrm{I}_{2} \mathrm{O}_{4}$.

${ }^{1} R_{\mathrm{A}+\mathrm{B}}$ is the reaction rate for reaction $\mathrm{A}+\mathrm{B} \rightarrow$ products and $J_{C}$ is the photodissociation rate constant (i.e. photolysis $\times$ concentration) for $\mathrm{C}+h v \rightarrow$ products. Units are molec. $\mathrm{cm}^{-3} \mathrm{~s}^{-1}$

${ }^{2} \mathrm{HO}_{\mathrm{x}}$ loss cycles represent a net change $2 \mathrm{O}_{3} \rightarrow 3 \mathrm{O}_{2}\left(\Delta \mathrm{O}_{\mathrm{x}}=-2\right)$ due to reactions $\mathrm{OH}+\mathrm{O} \rightarrow \mathrm{H}+\mathrm{O}_{2}$ and $\mathrm{OH}+\mathrm{O}_{3} \rightarrow \mathrm{HO}_{2}+\mathrm{O}_{2}$. As $\mathrm{O}_{\mathrm{x}}$ reactions with $\mathrm{OH}$ are faster than with $\mathrm{HO}_{2}$, only the rate determining steps (RDS) have been considered multiplied by two.

3 Reactions $\mathrm{XO}+\mathrm{HO}_{2} \rightarrow \mathrm{HOX}+\mathrm{O}_{2}$, with $\mathrm{X}=\mathrm{Cl}, \mathrm{Br}$ and $\mathrm{I}$, have been computed for each family with $\Delta \mathrm{O}_{\mathrm{x}}=-2$ because the photolysis of $\mathrm{HOX}$ produces an additional $\mathrm{O}_{\mathrm{x}}$ loss by the $\mathrm{OH}$ radical (i.e. $\mathrm{OH}+\mathrm{O}_{3} \rightarrow \mathrm{HO}_{2}+\mathrm{O}_{2}$ ). As these $\mathrm{XO}+\mathrm{HO}$ reaction are the rate limiting step, their loss rates have been multiplied by two.

ilies defined in Brasseur and Solomon (2005) with the inclusion of iodine-driven $\mathrm{O}_{\mathrm{x}}$ chemical losses $\left(\mathrm{IO}_{\mathrm{x}}\right.$ Loss $)$. The direct $\mathrm{O}_{\mathrm{x}}$ loss rate $\left(\mathrm{O}_{\mathrm{x}}\right.$ Loss $)$ represents the major ozone depleting family within the tropical MBL and FT, while in the upper troposphere the $\mathrm{HO}_{\mathrm{x}}$ Loss cycles become the predominant loss processes up to the tropical tropopause. Within the MBL, and as a consequence of the increased inorganic iodine loading due to the direct oceanic injection of reactive $\mathrm{I}_{2} / \mathrm{HOI}$ species, $\mathrm{IO}_{\mathrm{x} \text { Loss }}$ cycles represent the second most important ozone-depleting family $-\mathrm{IO}_{\mathrm{x} \text { Loss }}^{\mathrm{MBL}} \approx 17 \%(27 \%)$ for Base $\left(\mathrm{J}_{\mathrm{x}} \mathrm{O}_{\mathrm{y}}\right)$, respectively - surpassing in efficiency the contribution of $\mathrm{HO}_{\mathrm{x}}$ Loss. This additional source of inorganic iodine depends on the deposition of ozone on the ocean's surface, and then acts as a natural buffer for ozone pollution in the lower troposphere: e.g. the warming effect of anthropogenic ozone in the global marine troposphere can be reduced by at least 3-10\% when inorganic iodine sources are considered (see Prados-Roman et al. (2014) for details). The negative geochemical feedback loop between anthropogenic ozone and oceanic inorganic iodine emissions proposed by
Prados-Roman et al. (2014) exemplifies ocean biogeochemical cycles being affected by anthropogenic emissions. Comparatively, the overall effect of $\mathrm{BrO}_{\mathrm{x}}+\mathrm{ClO}_{\mathrm{x}}$ cycles constitute an ozone loss contribution smaller than $3 \%$ in the MBL, reaching a percentage contribution $>10 \%$ only in the upper troposphere. Note that our modelled daytime BrO levels averaged within the tropical MBL are $\sim(0.2-0.3)$ pptv, with higher values of up to a few pptv calculated within coastal locations and regions of strong convection (Fernandez et al., 2014). Notably, the iodine impact on the acceleration of ozone loss cycles peaks in the UT (that is, within the extensive tropical ring of atomic iodine), with a maximum contribution to the total ozone loss of $0.06(0.1) \mathrm{ppbv} \mathrm{day}^{-1}$ (representing $14(35) \%$ of total loss) reached at $11(13) \mathrm{km}$ of altitude for the Base $\left(J_{\mathrm{I}_{\mathrm{x}} \mathrm{O}_{\mathrm{y}}}\right)$ schemes, respectively. Our results indicate that, on average for the tropical troposphere, iodine-mediated ozone losses are responsible for at least 70 $85 \%$ of the total ozone depletion due to halogens.

The differences between $\mathrm{IO}_{\mathrm{x} \text { Loss }}$ and $\mathrm{BrO}_{\mathrm{x}}-\mathrm{ClO}_{\mathrm{x} \text { Loss }}$ contributions can be explained based on the higher reactivity 
Table 6. Integrated odd oxygen loss rates for each ozone depleting family within the troposphere.

\begin{tabular}{|c|c|c|c|c|c|c|c|c|}
\hline Simulation & & & Base & & & & $J_{I_{\mathrm{x}}} \mathrm{O}_{\mathrm{y}}$ & \\
\hline Tropics & MBL & FT & UT & Troposphere & MBL & FT & UT & Troposphere \\
\hline Ozone column (DU) & 1.31 & 13.68 & 9.01 & 24.18 & 1.23 & 13.11 & 8.73 & 23.25 \\
\hline$\Delta \mathrm{O}_{3}^{\mathrm{OnlyBr}}(\mathrm{DU})$ & -0.10 & -0.57 & -0.23 & -0.90 & -0.19 & -1.14 & -0.52 & -1.84 \\
\hline$\Delta \mathrm{O}_{3}^{\mathrm{NoVSL}}(\mathrm{DU})$ & -0.15 & -1.01 & -0.51 & -1.66 & -0.24 & -1.58 & -0.79 & -2.59 \\
\hline Ozone loss $\left(\mathrm{DU} \mathrm{yr}^{-1}\right)$ & 111.39 & 505.94 & 36.38 & 666.29 & 117.98 & 520.75 & 42.32 & 692.51 \\
\hline $\mathrm{O}_{\mathrm{X}}$ cycles $(\%)$ & 59 & 54 & 20 & 53 & 52 & 50 & 17 & 49 \\
\hline $\mathrm{HO}_{\mathrm{X}}$ cycles $(\%)$ & 20 & 35 & 58 & 34 & 18 & 32 & 47 & 31 \\
\hline $\mathrm{BrO}_{\mathrm{x}}-\mathrm{ClO}_{\mathrm{x}}(\%)$ & 3 & 3 & 11 & 4 & 3 & 3 & 9 & 3 \\
\hline $\mathrm{IO}_{\mathrm{x}}$ cycles $(\%)$ & 17 & 8 & 11 & 9 & 27 & 14 & 27 & 16 \\
\hline Mid-latitudes & MBL & FT & UT & Troposphere & MBL & FT & UT & Troposphere \\
\hline Ozone column (DU) & 1.91 & 17.85 & 10.64 & 30.66 & 1.83 & 17.19 & 10.29 & 29.57 \\
\hline$\Delta \mathrm{O}_{3}^{\text {OnlyBr }}(\mathrm{DU})$ & -0.09 & -0.56 & -0.18 & -0.82 & -0.17 & -1.22 & -0.54 & -1.91 \\
\hline$\Delta \mathrm{O}_{3}^{\mathrm{NoVSL}}(\mathrm{DU})$ & -0.16 & -1.22 & -0.52 & -1.90 & -0.24 & -1.88 & -0.87 & -2.98 \\
\hline Ozone loss $\left(\mathrm{DU} \mathrm{yr}^{-1}\right)$ & 73.66 & 351.68 & 29.35 & 471.36 & 75.39 & 358.19 & 33.03 & 483.05 \\
\hline $\mathrm{O}_{\mathrm{x}}$ cycles $(\%)$ & 51 & 42 & 15 & 42 & 48 & 40 & 13 & 40 \\
\hline $\mathrm{HO}_{\mathrm{x}}$ cycles $(\%)$ & 33 & 47 & 63 & 46 & 31 & 44 & 53 & 43 \\
\hline $\mathrm{BrO}_{\mathrm{X}}-\mathrm{ClO}_{\mathrm{X}}(\%)$ & 4 & 5 & 14 & 5 & 4 & 5 & 12 & 5 \\
\hline $\mathrm{IO}_{\mathrm{X}}$ cycles $(\%)$ & 11 & 6 & 7 & 6 & 17 & 11 & 21 & 12 \\
\hline
\end{tabular}

MBL: from the ocean surface up to $\sim 900 \mathrm{~m}$ a.s.l. $(\sim 900 \mathrm{hPa})$. An ocean mask discarding grid-boxes above land was applied.

FT: from $\sim 900 \mathrm{~m}(\sim 900 \mathrm{hPa})$ to $\sim 8.5 \mathrm{~km}(\sim 350 \mathrm{hPa})$.

UT: from $\sim 8.5 \mathrm{~km}(\sim 350 \mathrm{hPa})$ to the model tropopause. Values above the model tropopause were not considered.

Tropics: $\left(20^{\circ} \mathrm{N}-20^{\circ} \mathrm{S}\right)$.

Midlats: $\left(50-20^{\circ} \mathrm{N}\right) \&\left(20-50^{\circ} \mathrm{S}\right)$

$\Delta \mathrm{O}_{3}^{\mathrm{OnlyBr}}=\mathrm{O}_{3}^{\text {Iodine }}-\mathrm{O}_{3}^{\mathrm{OnlyBr}}$, where Iodine is either Base or $J_{\mathrm{I}_{\mathrm{x}} \mathrm{O}}$ schemes for the left and right panels of the table, respectively, and OnlyBr is an

equivalent simulation considering only bromine VSL sources. Analogously $\Delta \mathrm{O}_{3}^{\text {NoVSL }}=\mathrm{O}_{3}^{\text {Iodine }}-\mathrm{O}_{3}^{\text {NoVSL }}$, where NoVSL is a simulation where only long-lived bromine sources have been used (see text for details).

and therefore shorter lifetimes of iodine species: (i) due to the comparatively longer lifetimes of organic bromo- and chloro-carbons, inorganic bromine and chlorine cycles represent a major ozone loss process in the lower and middle stratosphere (Solomon et al., 1994; Salawitch et al., 2005); and (ii) the very fast catalytic reactions of iodine species make $\mathrm{IO}_{\mathrm{x}}$ ozone loss cycles to be up to 10 times faster than $\mathrm{BrO}_{\mathrm{x}}-\mathrm{ClO}_{\mathrm{x}}$ cycles for an identical $\mathrm{I}_{\mathrm{y}}$ and $\mathrm{Br}_{\mathrm{y}}$ basis (i.e. $\mathrm{IO}_{\mathrm{x} \text { Loss }} / \mathrm{I}_{\mathrm{y}} \approx 10 \times \mathrm{BrO}_{\mathrm{x}}-\mathrm{ClO}_{\mathrm{x} \text { Loss }} / \mathrm{Br}_{\mathrm{y}}$ ). The total $\mathrm{I}_{\mathrm{y}}$ abundance at the height where the relative $\mathrm{IO}_{\mathrm{x} \text { Loss }} \max$ imizes $(\sim 12 \mathrm{~km})$ is in the range $(0.66-0.81) \mathrm{pptv}$ for the (Base- $J_{\mathrm{I}_{\mathrm{x}} \mathrm{O}_{\mathrm{y}}}$ ) schemes, while for bromine, $\mathrm{Br}_{\mathrm{y}}^{12 \mathrm{~km}} \approx 1.0 \mathrm{pptv}$ and $\mathrm{Br}_{\mathrm{y}}^{17 \mathrm{~km}} \approx 3.0 \mathrm{pptv}$ (Fernandez et al., 2014). This indicates that even when $\mathrm{Br}_{\mathrm{y}}$ abundances are larger in the upper troposphere, the greater $\mathrm{O}_{3}$ destruction efficiency of $\mathrm{IO}_{\mathrm{x}}$ makes iodine the dominant halogen contributing to tropospheric ozone loss throughout the tropics and mid-latitudes (see Table 6). Indeed, our results show that iodine-driven ozone loss cycles are the second most important ozone depleting family both in the tropical MBL and in the tropical and mid-latitude upper troposphere. Therefore we suggest that global models oriented to estimate past and future projections of tropospheric ozone burden and trends should in- clude at least a simplified description of tropospheric iodine sources and inorganic chemistry, in addition to bromine.

Table 6 summarizes the integrated ozone column and the averaged ozone loss rate for different altitude intervals within the troposphere (MBL, FT, UT and total troposphere) within the tropical and mid-latitude regions. With the $J_{\mathrm{I}_{\mathrm{x}}} \mathrm{O}_{\mathrm{y}}$ scheme, the total tropospheric $\mathrm{O}_{3}$ column is $\sim 1$ DU smaller than for the Base scheme, representing an additional $4-7 \%$ reduction of tropospheric ozone. Adding up the contribution of bromine and iodine from VSL sources, and gas and heterogeneous chemistry, the tropical tropospheric $\mathrm{O}_{3}$ column for the $J_{\mathrm{I}_{\mathrm{x}} \mathrm{O}_{\mathrm{y}}}$ scheme is reduced by $2.6 \mathrm{DU}$ relative to the NoVSL simulation, representing more than $10 \%$ of the total tropospheric column. The vertical distribution of tropospheric ozone loss due to halogen chemistry within the tropics is very similar for both schemes considered here $(25 \%$ for the MBL, $65 \%$ for the FT and $10 \%$ for the UT). This indicates that most of the ozone loss due to iodine occurs in the free troposphere in agreement with previous estimates (Saiz-Lopez et al., 2012b).

Table 6 also presents the relative contribution of each of the odd oxygen families averaged at different altitude intervals and latitudinal bands. The overall impact of iodine chemistry on tropospheric ozone is larger in 

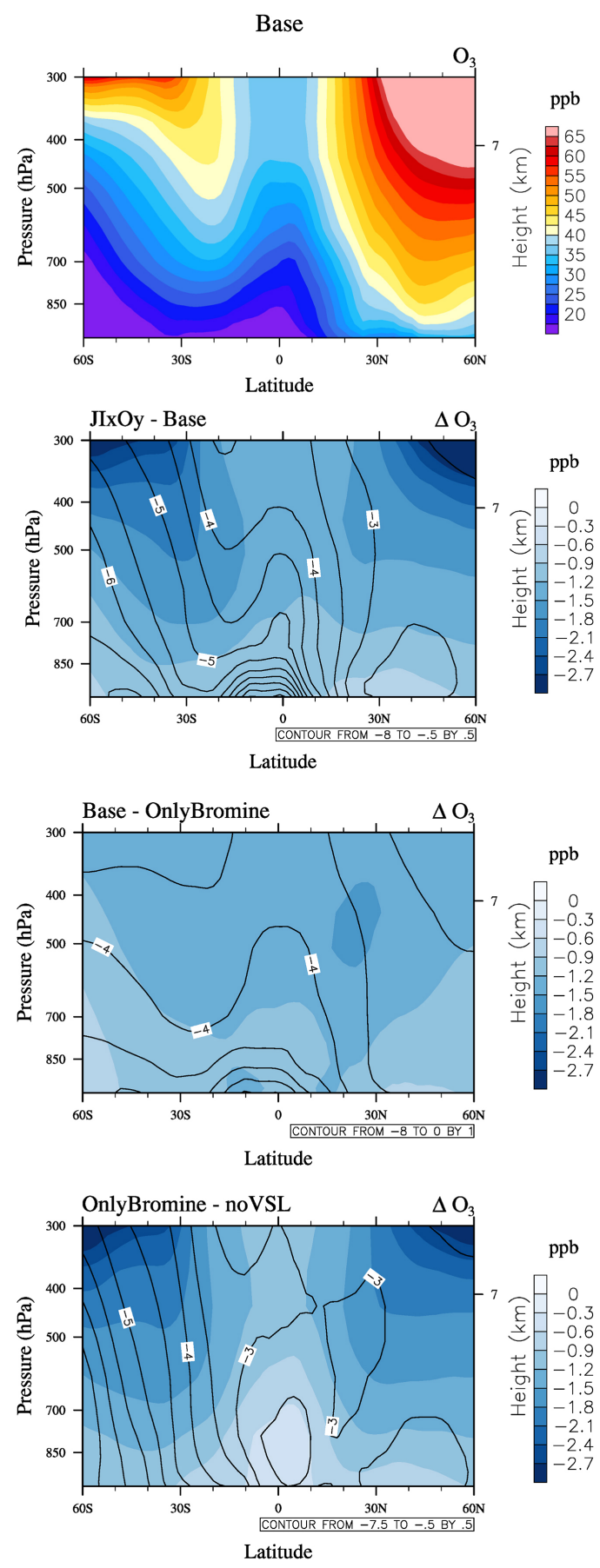

Figure 12. Zonal annual average distributions of tropospheric ozone changes for different model schemes considering iodine and bromine VSL sources: (a) $\mathrm{O}_{3}$ mixing ratios for the Base scheme (lower iodine loading); (b) difference between the higher and lower iodine schemes $\Delta \mathrm{O}_{3}\left(J_{\mathrm{I}_{\mathrm{x}} \mathrm{O}_{\mathrm{y}}}-\right.$ Base); (c) impact of lower iodine with respect to only bromine chemistry $\Delta \mathrm{O}_{3}$ (Base-OnlyBr); (d) impact of considering only bromine chemistry relative to only long-lived sources $\Delta \mathrm{O}_{3}($ OnlyBr-NoVSL $)$. The colour scale represents $24 \mathrm{~h}$ mean model differences in ppbv, while the black contour lines show the percentage change between each pair of simulations computed as $(\mathrm{A}-\mathrm{B}) / \mathrm{B} \times 100 \%$. the tropics than within the mid-latitudes, due to greater $\mathrm{I} / \mathrm{IO}$ ratio and larger contribution of $\mathrm{IO}_{\mathrm{x}}$ to total inorganic iodine within the I atom tropical ring. Even when the change in the tropospheric ozone column between the $J_{\mathrm{I}_{\mathrm{x}} \mathrm{O}_{\mathrm{y}}}$ and Base schemes is of similar magnitude for the tropics and the mid-latitudes $\left(\Delta \mathrm{O}_{3}{ }^{\text {Tropics }} \approx-1.0 \mathrm{DU}\right.$ and $\Delta \mathrm{O}_{3}$ Midlats $\left.\approx-1.1 \mathrm{DU}\right)$, the ozone loss acceleration due to the increase in iodine loading is $\sim 2$ times larger for the $J_{\mathrm{I}_{\mathrm{x}} \mathrm{O}_{\mathrm{y}}}$ scheme within the tropics $\left(\Delta \mathrm{O}_{3}\right.$ Loss $^{\text {Tropics }} \approx 26.2 \mathrm{DU} \mathrm{yr}^{-1}$ and $\Delta \mathrm{O}_{3}$ Loss ${ }^{\text {Midlats }} \approx 11.7 \mathrm{DU} \mathrm{yr}^{-1}$ ). Our results indicate that the integrated contribution of the iodine system to the total rate of tropospheric ozone loss over the tropics is 2.2 (5.3) times larger than that of chlorine and bromine chemistry for the Base $\left(J_{\mathrm{I}_{\mathrm{x}} \mathrm{O}_{\mathrm{y}}}\right)$ schemes, compared to a $1.2(2.4)$ relative enhancement over the mid-latitudes. Notably, in the MBL iodine-mediated ozone loss rate is almost an order of magnitude faster than the combined rates of $\mathrm{BrO}_{\mathrm{x}}+\mathrm{ClO}_{\mathrm{x}}$ cycles, even when the Base scheme is considered. Within the lower TTL, $\mathrm{BrO}_{\mathrm{x}}-\mathrm{ClO}_{\mathrm{x} \text { Loss }}$ catalytic cycles result in higher ozone losses than $\mathrm{IO}_{\mathrm{x}}$ Loss cycles only for the Base simulation. Note however that if photolysis of higher iodine oxides is allowed in the model, the $\mathrm{IO}_{\mathrm{x}}$ catalytic ozone depleting cycles continue to be more efficient than $\mathrm{BrO}_{\mathrm{x}}-\mathrm{ClO}_{\mathrm{x}}$ Loss cycles throughout most of the TTL (Fig. 13).

\section{Summary and conclusions}

We propose the existence of a "tropical ring of atomic iodine" that circles the tropics with the sun. The tropical ring extends from $30^{\circ} \mathrm{S}$ to $30^{\circ} \mathrm{N}$ and maximizes at a height of $11-14 \mathrm{~km}$, with volume mixing ratios ranging from 0.2 to 0.8 pptv. This photochemical phenomenon is driven by the fast photolysis rate of IO and the Arrhenius behaviour of the $\mathrm{I}+\mathrm{O}_{3}$ reaction, and appears naturally in the upper troposphere where ambient temperatures minimize and ozone abundances are at least one order of magnitude below stratospheric levels. Within this tropical ring, noontime annual average I/IO ratios of $\sim 3$ are modelled, reaching maximum values of $\sim 20$ during events of vigorous convection. Inorganic iodine surpasses the contribution of organic VSL species throughout the troposphere, being $\mathrm{CH}_{3} \mathrm{I}$ the dominant source that maintains $\mathrm{I}_{\mathrm{y}}$ levels in the FT and UT. Within the MBL and FT, HOI is the dominant $\mathrm{I}_{\mathrm{y}}$ species, both during the day and at night. The other abundant nighttime reservoirs are $\mathrm{IONO}_{2}$ in the UT and the di-halogen molecules $\left(\mathrm{I}_{2}, \mathrm{IBr}\right.$ and $\mathrm{ICl}$ ) in the MBL.

Finally, we suggest that reducing uncertainties on the photochemistry of $\mathrm{I}_{\mathrm{x}} \mathrm{O}_{\mathrm{y}}$ species constitutes the main challenge to our current knowledge of atmospheric iodine chemistry. We show that if the photodissociation of $\mathrm{I}_{\mathrm{x}} \mathrm{O}_{\mathrm{y}}$ is neglected, then these higher oxides accumulate in the atmosphere due to their slow thermal decomposition and became an effective sink of active iodine in the FT and UT. Experimental and theoretical studies on the $\mathrm{I}_{\mathrm{x}} \mathrm{O}_{\mathrm{y}}$ photochemistry are required 


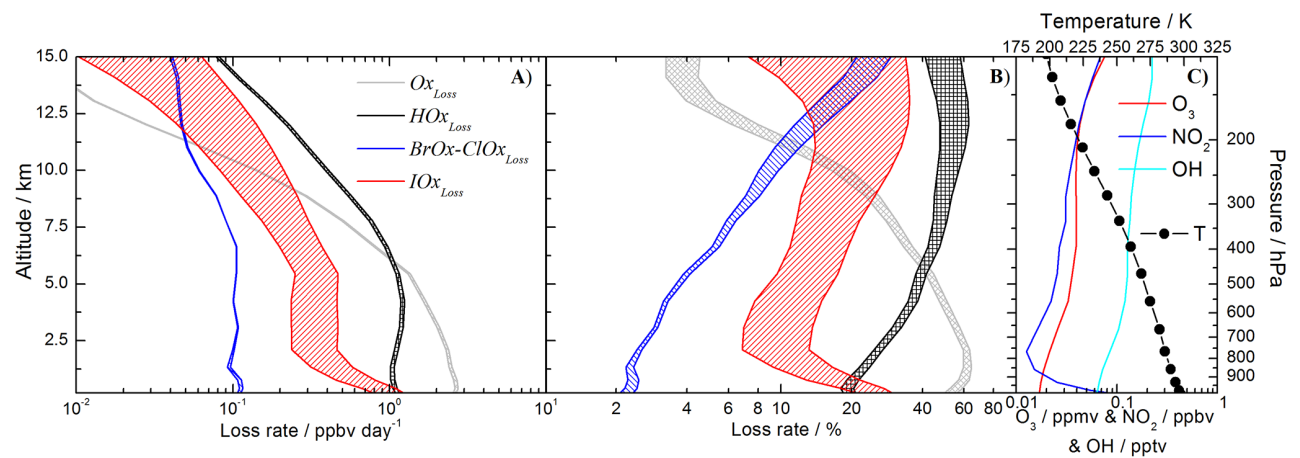

Figure 13. Modelled range of odd oxygen destruction for each of the ozone depleting families: (a) Annual total loss rates for the $\mathrm{O}_{\mathrm{x}}$, $\mathrm{HO}_{\mathrm{x}}$, $\mathrm{BrO}_{\mathrm{x}}-\mathrm{ClO}_{\mathrm{x}}$ and $\mathrm{IO}_{\mathrm{x}}$ families within the tropical troposphere $\left(20^{\circ} \mathrm{N}-20^{\circ} \mathrm{S}\right)$; (b) Percentage contribution of each family to the total loss rate for each scheme; (c) Vertical profiles of $\mathrm{O}_{3}, \mathrm{NO}_{2}, \mathrm{OH}$ and temperature within the tropics. Lower and upper limits of the range are for the Base and $J_{\mathrm{I}_{\mathrm{x}} \mathrm{O}_{\mathrm{y}}}$ schemes, respectively.

to improve the knowledge on the inorganic iodine burden and its oxidative impacts in the troposphere. Based in our modelled range of inorganic iodine loading $(0.7-1.0)$ pptv in the FT dependent on the consideration or not of $\mathrm{I}_{\mathrm{x}} \mathrm{O}_{\mathrm{y}}$ photolysis, we show for the first time with a global model that iodine is the second most important ozone-depleting family in the tropical MBL and in the global marine UT, representing between (17-27)\% and (11-27)\% of the total ozone loss within each respective region. Therefore, we suggest global chemistry-climate models (CCMs) should include at least a simplified representation of iodine tropospheric chemistry for future CCM-Validation and CCM-Intercomparison projects concerned with tropospheric ozone over the oceans for past, present and future scenarios.

Acknowledgements. This work was supported by the Consejo Superior de Investigaciones Cientificas (CSIC), Spain. The National Center for Atmospheric Research (NCAR) is funded by the National Science Foundation NSF. Computing resources (ark:/85065/d7wd3xhc) were provided by the Climate Simulation Laboratory at NCAR's Computational and Information Systems Laboratory (CISL), sponsored by the NSF and other agencies. The CESM project (which includes CAM-Chem) is supported by the NSF and the Office of Science (BER) of the US Department of Energy. This work was also sponsored by the NASA Atmospheric Composition Modeling and Analysis Program Activities (ACMAP), grant/cooperative agreement number NNX11AH90G. The authors are grateful to J. M. C. Plane for support and helpful discussions. R. P. Fernandez would like to thank ANPCyT (PICTPRH 2009-0063) and SeCTyP-UNCuyo for financial support.

Edited by: A. Dastoor

\section{References}

Alicke, B., Hebestreit, K., Stutz, J., and Platt, U.: Iodine oxide in the marine boundary layer, Nature, 397, 572-573, doi:10.1038/17508, 1999.

Allan, B. J. and Plane, J. M. C.: A Study of the Recombination of IO with $\mathrm{NO}_{2}$ and the Stability of $\mathrm{INO}_{3}$ ?: Implications for the Atmospheric Chemistry of Iodine, J. Phys. Chem. A, 106, 86348641, doi:10.1021/jp020089q, 2002.

Allan, B. J., McFiggans, G., Plane, J. M. C., and Coe, H.: Observations of iodine monoxide in the remote marine boundary layer, $\mathrm{J}$ Geophys. Res., 105, 14363, doi:10.1029/1999JD901188, 2000.

Atkinson, H. M., Huang, R.-J., Chance, R., Roscoe, H. K., Hughes, C., Davison, B., Schönhardt, A., Mahajan, A. S., Saiz-Lopez, A., Hoffmann, T., and Liss, P. S.: Iodine emissions from the sea ice of the Weddell Sea, Atmos. Chem. Phys., 12, 11229-11244, doi:10.5194/acp-12-11229-2012, 2012.

Atkinson, R., Baulch, D. L., Cox, R. A., Crowley, J. N., Hampson, R. F., Hynes, R. G., Jenkin, M. E., Rossi, M. J., and Troe, J.: Evaluated kinetic and photochemical data for atmospheric chemistry: Volume III - gas phase reactions of inorganic halogens, Atmos. Chem. Phys., 7, 981-1191, doi:10.5194/acp-7-981-2007, 2007.

Atkinson, R., Baulch, D. L., Cox, R. A., Crowley, J. N., Hampson, R. F., Hynes, R. G., Jenkin, M. E., Rossi, M. J., Troe, J., and Wallington, T. J.: Evaluated kinetic and photochemical data for atmospheric chemistry: Volume IV - gas phase reactions of organic halogen species, Atmos. Chem. Phys., 8, 4141-4496, doi:10.5194/acp-8-4141-2008, 2008.

Bale, C. S. E., Canosa-mas, C. E., Shallcross, E., and Wayne, R. P.: A discharge - flow study of the kinetics of the reactions of IO with $\mathrm{CH}_{3} \mathrm{O}_{2}$ and $\mathrm{CF}_{3} \mathrm{O}_{2}$, Phys. Chem. Chem. Phys., 7, 2164 2172, 2005.

Bale, C. S. E., Ingham, T., Commane, R., Heard, D. E., and Bloss, W. J.: Novel measurements of atmospheric iodine species by resonance fluorescence, J. Atmos. Chem., 60, 51-70, doi:10.1007/s10874-008-9108-z, 2008.

Bedjanian, Y., Le Bras, G., and Poulet, G.: Kinetic study of the $\mathrm{Br}+\mathrm{IO}, \mathrm{I}+\mathrm{BrO}$ and $\mathrm{Br}+\mathrm{I}_{2}$ reactions. Heat of formation of the BrO radical, Chem. Phys. Lett., 266, 233-238, doi:10.1016/S0009-2614(97)01530-3, 1997. 
Bell, N., Hsu, L., Jacob, D. J., Schultz, M. G., Blake, D. R., Butler, J. H., King, D. B., Lobert, J. M., and Maier-Reimer, E.: Methyl iodide: Atmospheric budget and use as a tracer of marine convection in global models, J. Geophys. Res., 107, 4340, doi:10.1029/2001JD001151, 2002.

Bloss, W. J., Rowley, D. M., Cox, R. A., and Jones, R. L.: Kinetics and Products of the IO Self-Reaction, J. Phys. Chem. A, 105(33), 7840-7854, doi:10.1021/jp0044936, 2001.

Bloss, W. J., Lee, J. D., Johnson, G. P., Sommariva, R., Heard, D. E., Saiz-Lopez, A., Plane, J. M. ., McFiggans, G. B., Coe, H., Flynn, M., Williams, P., Rickard, A. R., and Fleming, Z. L.: Impact of halogen monoxide chemistry upon boundary layer $\mathrm{OH}$ and $\mathrm{HO}_{2}$ concentrations at a coastal site, Geophys. Res. Lett., 32, L06814, doi:10.1029/2004GL022084, 2005.

Bösch, H., Camy-Peyret, C., Chipperfield, M. P., Fitzenberger, R., Harder, H., Platt, U., and Pfeilsticker, K.: Upper limits of stratospheric IO and OIO inferred from center-to-limb-darkeningcorrected balloon-borne solar occultation visible spectra: Implications for total gaseous iodine and stratospheric ozone, J. Geophys. Res., 108, 4455, doi:10.1029/2002JD003078, 2003.

Brasseur, G. and Solomon, S.: Aeronomy of the Middle Atmosphere: Chemistry and Physics of the Stratosphere and Mesosphere, 3rd Editio., Springer, Dordrecht, The Netherlands, Chapter 5, 265-442, 2005.

Butz, A., Bösch, H., Camy-Peyret, C., Chipperfield, M. P., Dorf, M., Kreycy, S., Kritten, L., Prados-Román, C., Schwärzle, J., and Pfeilsticker, K.: Constraints on inorganic gaseous iodine in the tropical upper troposphere and stratosphere inferred from balloon-borne solar occultation observations, Atmos. Chem. Phys., 9, 7229-7242, doi:10.5194/acp-9-7229-2009, 2009.

Calvert, J. G. and Lindberg, S. E.: Potential influence of iodinecontaining compounds on the chemistry of the troposphere in the polar spring. I. Ozone depletion, Atmos. Environ., 38, 50875104, doi:10.1016/j.atmosenv.2004.05.049, 2004.

Carpenter, L. J., Archer, S. D., and Beale, R.: Oceanatmosphere trace gas exchange., Chem. Soc. Rev., 41, 6473-506, doi:10.1039/c2cs35121h, 2012.

Carpenter, L. J., MacDonald, S. M., Shaw, M. D., Kumar, R., Saunders, R. W., Parthipan, R., Wilson, J., and Plane, J. M. C.: Atmospheric iodine levels influenced by sea surface emissions of inorganic iodine, Nat. Geosci., 6, 108-111, doi:10.1038/ngeo1687, 2013.

Chambers, R. M., Heard, A. C., and Wayne, R. P.: Inorganic gasphase reactions of the nitrate radical: iodine + nitrate radical and iodine atom + nitrate radical, J. Phys. Chem., 96, 3321-3331, doi:10.1021/j100187a028, 1992.

Chameides, W. L., and Davis, D. D.: Iodine: Its possible role in tropospheric photochemistry, J. Geophys. Res., 85(C12), 7383, doi:10.1029/JC085iC12p07383, 1980.

Daehlie, G., and Kjekshus, A.: Iodine Oxides, Acta Chem. Scand., 18, 114-156, 1964.

Davis, D., Crawford, J., Liu, S., McKeen, S., Bandy, A., Thornton, D., Rowland, F., and Blake, D.: Potential impact of iodine on tropospheric levels of ozone and other critical oxidants, J. Geophys. Res., 101, 2135, doi:10.1029/95JD02727, 1996.

Dillon, T. J., Karunanandan, R., and Crowley, J. N.: The reaction of $\mathrm{IO}$ with $\mathrm{CH}_{3} \mathrm{SCH}_{3}$ : products and temperature dependent rate coefficients by laser induced fluorescence., Phys. Chem. Chem. Phys., 8, 847-55, doi:10.1039/b514718b, 2006a.
Dillon, T. J., Tucceri, M. E., and Crowley, J. N.: Laser induced fluorescence studies of iodine oxide chemistry: Part II. The reactions of $\mathrm{IO}$ with $\mathrm{CH}_{3} \mathrm{O}_{2}, \mathrm{CF}_{3} \mathrm{O}_{2}$ and $\mathrm{O}_{3}$, Phys. Chem. Chem. Phys., 8, 5185-5198, doi:10.1039/b611116e, 2006b.

Dillon, T. J., Tucceri, M. E., Sander, R., and Crowley, J. N.: LIF studies of iodine oxide chemistry. Part 3. Reactions $\mathrm{IO}+\mathrm{NO}_{3} \rightarrow \mathrm{OIO}+\mathrm{NO}_{2}, \mathrm{I}+\mathrm{NO}_{3}->\mathrm{IO}+\mathrm{NO}_{2}$, and $\mathrm{CH} 2 \mathrm{I}+\mathrm{O}_{2}->$ (products): implications for the chemistry of the marine atmosphere at night., Phys. Chem. Chem. Phys., 10, 1540-54, doi:10.1039/b717386e, 2008.

Dix, B., Baidar, S., Bresch, J. F., Hall, S. R., Schmidt, K. S., Wang, S., and Volkamer, R.: Detection of iodine monoxide in the tropical free troposphere., P. Natl. Acad. Sci. USA, 110, 2035-2040, doi:10.1073/pnas.1212386110, 2013.

Dooley, K. S., Geidosch, J. N., and North, S. W.: Ion imaging study of IO radical photodissociation?: Accurate bond dissociation energy determination, Chem. Phys. Lett., 457, 303-306, doi:10.1016/j.cplett.2008.04.009, 2008.

Drougas, E., and Kosmas, A. M.: Ab Initio Characterization of $\left(\mathrm{CH}_{3} \mathrm{IO}_{3}\right)$ Isomers and the $\mathrm{CH}_{3} \mathrm{O}_{2}+\mathrm{IO}$ Reaction Pathways, J. Phys. Chem. A, 6, 2007.

Emmons, L. K., Walters, S., Hess, P. G., Lamarque, J.-F., Pfister, G. G., Fillmore, D., Granier, C., Guenther, A., Kinnison, D., Laepple, T., Orlando, J., Tie, X., Tyndall, G., Wiedinmyer, C., Baughcum, S. L., and Kloster, S.: Description and evaluation of the Model for Ozone and Related chemical Tracers, version 4 (MOZART-4), Geosci. Model Dev., 3, 43-67, doi:10.5194/gmd3-43-2010, 2010.

Enami, S., Yamanaka, T., Hashimoto, S., and Kawasaki, M.: Kinetic Study of IO Radical with $\mathrm{RO}_{2}\left(\mathrm{R}=\mathrm{CH}_{3}, \mathrm{C}_{2} \mathrm{H}_{5}\right.$, and $\left.\mathrm{CF}_{3}\right)$ Using Cavity Ring-Down Spectroscopy, J. Phys. Chem. A., 2, 7-12, 2006.

Fernandez, R. P., Salawitch, R. J., Kinnison, D. E., Lamarque, J.-F., and Saiz-Lopez, A.: Bromine partitioning in the tropical tropopause layer: implications for stratospheric injection, Atmos. Chem. Phys. Discuss., 14, 17857-17905, doi:10.5194/acpd-1417857-2014, 2014.

Gálvez, O., Gómez Martín, J. C., Gómez, P. C., Saiz-Lopez, A., and Pacios, L. F.: A theoretical study on the formation of iodine oxide aggregates and monohydrates, Phys. Chem. Chem. Phys., 15, 15572-15583, doi:10.1039/c3cp51219c, 2013.

Garland, J. A. and Curtis, H.: Emission of iodine from the sea surface in the presence of ozone, J. Geophys. Res., 86, 3183, doi:10.1029/JC086iC04p03183, 1981.

Gilles, M. K., Turnipseed, A. A., Burkholder, J. B., and Ravishankara, A. R.: A study of the $\mathrm{Br}+\mathrm{IO} \rightarrow \mathrm{I}+\mathrm{BrO}$ and the reverse reaction, Chem. Phys. Lett., 272, 75-82, doi:10.1016/S00092614(97)00485-5, 1997.

Glowacki, D. R., Liang, C.-H., Morley, C., Pilling, M. J., and Robertson, S. H.: MESMER: an open-source master equation solver for multi-energy well reactions., J. Phys. Chem. A, 116(38), 9545-60, doi:10.1021/jp3051033, 2012.

Gómez Martín, J. C. and Plane, J. M. C.: Determination of the OIO bond dissociation energy by photofragment excitation spectroscopy, Chem. Phys. Lett., 474, 79-83, 2009.

Gómez Martín, J. C., Spietz, P., and Burrows, J. P.: Spectroscopic studies of the $\mathrm{I}_{2} / \mathrm{O}_{3}$ photochemistry. Part 1: Determination of the absolute absorption cross sections of iodine oxides of atmo- 
spheric relevance, J. Photochem. Photobiol. A Chem., 176, 1538, doi:10.1016/j.jphotochem.2005.09.024, 2005.

Gómez Martín, J. C., Spietz, P., and Burrows, J. P.: Kinetic and mechanistic studies of the $\mathrm{I}(2) / \mathrm{O}(3)$ photochemistry., J. Phys. Chem. A, 111, 306-20, doi:10.1021/jp061186c, 2007.

Gómez Martín, J. C., Gálvez, O., Baeza-Romero, M. T., Ingham, T., Plane, J. M. C., and Blitz, M. A.: On the mechanism of iodine oxide particle formation, Phys. Chem. Chem. Phys., 15, 1561215622, doi:10.1039/c3cp51217g, 2013a.

Gómez Martín, J. C., Mahajan, A. S., Hay, T. D., Prados-Román, C., Ordóñez, C., MacDonald, S. M., Plane, J. M. C., Sorribas, M., Gil, M., Paredes Mora, J. F., Agama Reyes, M. V., Oram, D. E., Leedham, E., and Saiz-Lopez, A.: Iodine chemistry in the eastern Pacific marine boundary layer, J. Geophys. Res. Atmos., 118, 887-904, doi:10.1002/jgrd.50132, 2013b.

Großmann, K., Frieß, U., Peters, E., Wittrock, F., Lampel, J., Yilmaz, S., Tschritter, J., Sommariva, R., von Glasow, R., Quack, B., Krüger, K., Pfeilsticker, K., and Platt, U.: Iodine monoxide in the Western Pacific marine boundary layer, Atmos. Chem. Phys., 13, 3363-3378, doi:10.5194/acp-13-3363-2013, 2013.

Hayase, S., Yabushita, A., Kawasaki, M., Enami, S., Hoffmann, M. R., and Colussi, A. J.: Heterogeneous reaction of gaseous ozone with aqueous iodide in the presence of aqueous organic species, J. Phys. Chem. A, 114, 6016-6021, doi:10.1021/jp101985f, 2010.

Hoffmann, T., O’Dowd, C., and Seinfeld, J.: Iodine oxide homogeneous nucleation: An explanation for coastal new particle production, Geophys. Res. Lett., 28, 1949-1952, 2001.

Huang, R. J., Seitz, K., Neary, T., O’Dowd, C. D., Platt, U., and Hoffmann, T.: Observations of high concentrations of $\mathrm{I}_{2}$ and IO in coastal air supporting iodine-oxide driven coastal new particle formation, Geophys. Res. Lett., 37, L03803, doi:10.1029/2009GL041467, 2010.

Jenkin, M. E., Cox, R. A., and Candeland, D. E.: Photochemical aspects of tropospheric iodine behaviour, J. Atmos. Chem., 2, 359-375, doi:10.1007/BF00130748, 1985.

Jimenez, J. L., Bahreini, R., Cocker III, R., Zhuang, H., Varutbanhkul, V., Flagan, R., Seinfeld, J., O’Dowd, C., and Hoffmann, T.: New particle formation from photooxidation of diiodomethane $\left(\mathrm{CH}_{2} \mathrm{I}_{2}\right)$, J. Geophys. Res., 108, 4318, doi:10.1029/2002JD002452, 2003.

Jones, C. E., Hornsby, K. E., Sommariva, R., Dunk, R. M., von Glasow, R., McFiggans, G., and Carpenter, L. J.: Quantifying the contribution of marine organic gases to atmospheric iodine, Geophys. Res. Lett., 37, L18804, doi:10.1029/2010GL043990, 2010.

Kaltsoyannis, N. and Plane, J. M. C.: Quantum chemical calculations on a selection of iodine-containing species (IO, $\mathrm{OIO}, \mathrm{INO}_{3},(\mathrm{IO})_{2}, \mathrm{I}_{2} \mathrm{O}_{3}, \mathrm{I}_{2} \mathrm{O}_{4}$ and $\left.\mathrm{I}_{2} \mathrm{O}_{5}\right)$ of importance in the atmosphere., Phys. Chem. Chem. Phys., 10, 1723-1733, doi:10.1039/b715687c, 2008

Kinnison, D. E., Brasseur, G. P., Walters, S., Garcia, R. R., Marsh, D. R., Sassi, F., Harvey, V. L., Randall, C. E., Emmons, L., Lamarque, J. F., Hess, P., Orlando, J. J., Tie, X. X., Randel, W., Pan, L. L., Gettelman, A., Granier, C., Diehl, T., Niemeier, U., and Simmons, A. J.: Sensitivity of chemical tracers to meteorological parameters in the MOZART-3 chemical transport model, J. Geophys. Res., 112, D20302, doi:10.1029/2006JD007879, 2007.
Knyazev, V. D., and Slagle, I. R.: Thermochemistry of the R-O Bond in Alkyl and Chloroalkyl Peroxy Radicals, J. Phys. Chem. A., 102, 1770-1778, 1998.

Lamarque, J.-F., Emmons, L. K., Hess, P. G., Kinnison, D. E., Tilmes, S., Vitt, F., Heald, C. L., Holland, E. A., Lauritzen, P. H., Neu, J., Orlando, J. J., Rasch, P. J., and Tyndall, G. K.: CAM-chem: description and evaluation of interactive atmospheric chemistry in the Community Earth System Model, Geosci. Model Dev., 5, 369-411, doi:10.5194/gmd-5-369-2012, 2012.

Lancar, I. T., Mellouki, A., and Poulet, G.: Kinetics of the reactions of hydrogen iodide with hydroxyl and nitrate radicals, Chem. Phys. Lett., 177, 554-558, doi:10.1016/0009-2614(91)90083-L, 1991.

Laszlo, B., Huie, R. E., Kurylo, M. J., and Miziolek, A. W.: Kinetic studies of the reactions of BrO and IO radicals, J. Geophys. Res., 102, 1523, doi:10.1029/96JD00458, 1997.

Lawler, M. J., Mahajan, A. S., Saiz-Lopez, A., and Saltzman, E. S.: Observations of $\mathrm{I}_{2}$ at a remote marine site, Atmos. Chem. Phys., 14, 2669-2678, doi:10.5194/acp-14-2669-2014, 2014.

MacDonald, S. M., Gómez Martín, J. C., Chance, R., Warriner, S., Saiz-Lopez, A., Carpenter, L. J., and Plane, J. M. C.: A laboratory characterisation of inorganic iodine emissions from the sea surface: dependence on oceanic variables and parameterisation for global modelling, Atmos. Chem. Phys., 14, 5841-5852, doi:10.5194/acp-14-5841-2014, 2014.

Mahajan, A. S., Plane, J. M. C., Oetjen, H., Mendes, L., Saunders, R. W., Saiz-Lopez, A., Jones, C. E., Carpenter, L. J., and McFiggans, G. B.: Measurement and modelling of tropospheric reactive halogen species over the tropical Atlantic Ocean, Atmos. Chem Phys., 10, 4611-4624, doi:10.5194/acp-10-4611-2010, 2010.

Mahajan, A. S., Sorribas, M., Gómez Martín, J. C., MacDonald, S. M., Gil, M., Plane, J. M. C., and Saiz-Lopez, A.: Concurrent observations of atomic iodine, molecular iodine and ultrafine particles in a coastal environment, Atmos. Chem. Phys., 11, 25452555, doi:10.5194/acp-11-2545-2011, 2011.

Mahajan, A. S., Gómez Martín, J. C., Hay, T. D., Royer, S.-J., Yvon-Lewis, S., Liu, Y., Hu, L., Prados-Roman, C., Ordóñez, C., Plane, J. M. C., and Saiz-Lopez, A.: Latitudinal distribution of reactive iodine in the Eastern Pacific and its link to open ocean sources, Atmos. Chem. Phys., 12, 11609-11617, doi:10.5194/acp-12-11609-2012, 2012.

McFiggans, G., Plane, J. M. C., Allan, B. J., Carpenter, L. J., Coe, H., and O'Dowd, C.: A modeling study of iodine chemistry in the marine boundary layer, J. Geophys. Res., 105, 14371-14385, doi:10.1029/1999JD901187, 2000.

McFiggans, G., Coe, H., Burgess, R., Allan, J., Cubison, M., Alfarra, M. R., Saunders, R., Saiz-Lopez, A., Plane, J. M. C., Wevill, D., Carpenter, L., Rickard, a. R., and Monks, P. S.: Direct evidence for coastal iodine particles from Laminaria macroalgae - linkage to emissions of molecular iodine, Atmos. Chem. Phys., 4, 701-713, doi:10.5194/acp-4-701-2004, 2004.

McFiggans, G., Bale, C. S. E., Ball, S. M., Beames, J. M., Bloss, W. J., Carpenter, L. J., Dorsey, J., Dunk, R., Flynn, M. J., Furneaux, K. L., Gallagher, M. W., Heard, D. E., Hollingsworth, a. M., Hornsby, K., Ingham, T., Jones, C. E., Jones, R. L., Kramer, L. J., Langridge, J. M., Leblanc, C., LeCrane, J.-P., Lee, J. D., Leigh, R. J., Longley, I., Mahajan, a. S., Monks, P. S., Oetjen, H., Orr-Ewing, a. J., Plane, J. M. C., Potin, P., Shillings, a. J. 
L., Thomas, F., von Glasow, R., Wada, R., Whalley, L. K., and Whitehead, J. D.: Iodine-mediated coastal particle formation: an overview of the Reactive Halogens in the Marine Boundary Layer (RHaMBLe) Roscoff coastal study, Atmos. Chem. Phys., 10, 2975-2999, doi:10.5194/acp-10-2975-2010, 2010.

Montzka, S. A., Reimann, S., Engel, A., Krüger, K., O`Doherty, S., and Sturges, W. T.: Ozone-Depleting Substances (ODSs) and Related Chemicals, Chapter 1 in Scientific Assessment of Ozone Depletion: 2010, Global Ozone Research and Monitoring Project-Report No. 52, Geneva, Switzerland., 2011.

Mössinger, J. C., Shallcross, D. E., and Anthony Cox, R.: UV-VIS absorption cross-sections and atmospheric lifetimes of $\mathrm{CH}_{2} \mathrm{Br}_{2}$, $\mathrm{CH}_{2} \mathrm{I}_{2}$ and $\mathrm{CH}_{2} \mathrm{BrI}$, J. Chem. Soc. Faraday Trans., 94, 13911396, doi:10.1039/a709160e, 1998.

Neu, J. L. and Prather, M. J.: Toward a more physical representation of precipitation scavenging in global chemistry models: cloud overlap and ice physics and their impact on tropospheric ozone, Atmos. Chem. Phys., 12(7), 3289-3310, doi:10.5194/acp12-3289-2012, 2012.

O’Dowd, C., Jimenez, J., Bahrelnl, R., Flagan, R., Seinfeld, J., Hameri, K., Pirjola, L., Kulmala, M., Jennings, S. G., and Hoffmann, T.: Marine aerosol formation from biogenic iodine emissions, Nature, 417, 1-5, doi:doi:10.1038/nature00775, 2002.

Ordóñez, C., Lamarque, J.-F., Tilmes, S., Kinnison, D. E., Atlas, E. L., Blake, D. R., Sousa Santos, G., Brasseur, G., and Saiz-Lopez, A.: Bromine and iodine chemistry in a global chemistry-climate model: description and evaluation of very short-lived oceanic sources, Atmos. Chem. Phys., 12, 1423-1447, doi:10.5194/acp12-1423-2012, 2012.

Parrish, D. D., Lamarque, J.-F., Naik, V., Horowitz, L., Shindell, D. T., Staehelin, J., Derwent, R., Cooper, O. R., Tanimoto, H., Volz-Thomas, A., Gilge, S., Scheel, H.-E., Steinbacher, M., and Fröhlich, M.: Long-term changes in lower tropospheric baseline ozone concentrations: Comparing chemistry-climate models and observations at northern midlatitudes, J. Geophys. Res. Atmos., 119, 5719-5736, doi:10.1002/2013JD021435, 2014.

Pechtl, S., Lovejoy, E. R., Burkholder, J. B., and von Glasow, R.: Modeling the possible role of iodine oxides in atmospheric new particle formation, Atmos. Chem. Phys., 6, 505-523, doi:10.5194/acp-6-505-2006, 2006.

Plane, J. M. C., Joseph, D. M., Allan, B. J., Ashworth, S. H., and Francisco, J. S.: An experimental and theoretical study of the reactions $\mathrm{OIO}+\mathrm{NO}$ and $\mathrm{OIO}+\mathrm{OH}$, J. Phys. Chem. A, 110, 93100, doi:10.1021/jp055364y, 2006.

Prados-Roman, C., Cuevas, C. a., Fernandez, R. P., Kinnison, D. E., Lamarque, J.-F., and Saiz-Lopez, A.: A negative feedback between anthropogenic ozone pollution and enhanced ocean emissions of iodine, Atmos. Chem. Phys. Discuss., 14, 21917-21942, doi:10.5194/acpd-14-21917-2014, 2014.

Puentedura, O., Gil, M., Saiz-Lopez, A., Hay, T., Navarro-Comas, M., Gómez-Pelaez, A., Cuevas, E., Iglesias, J., and Gomez, L.: Iodine monoxide in the north subtropical free troposphere, Atmos. Chem. Phys., 12, 4909-4921, doi:10.5194/acp-12-49092012, 2012.

Rattigan, O. V., Shallcross, D. E., and Anthony Cox, R.: UV absorption cross-sections and atmospheric photolysis rates of $\mathrm{CF}_{3} \mathrm{I}$, $\mathrm{CH}_{3} \mathrm{I}, \mathrm{C}_{2} \mathrm{H}_{5} \mathrm{I}$ and $\mathrm{CH}_{2} \mathrm{ICl}$, J. Chem. Soc. Faraday Trans., 93, 2839-2846, doi:10.1039/a701529a, 1997.
Rayner, N. A.: Global analyses of sea surface temperature, sea ice, and night marine air temperature since the late nineteenth century, J. Geophys. Res., 108, 4407, doi:10.1029/2002JD002670, 2003.

Roehl, C. M., Burkholder, J. B., Moortgat, G. K., Ravishankara, A. R., and Crutzen, P. J.: Temperature dependence of UV absorption cross sections and atmospheric implications of several alkyl iodides, J. Geophys. Res., 102, 12819-12829, doi:10.1029/97JD00530, 1997.

Saiz-Lopez, A. and von Glasow, R.: Reactive halogen chemistry in the troposphere., Chem. Soc. Rev., 41, 6448-6472, doi:10.1039/c2cs35208g, 2012.

Saiz-Lopez, A. and Plane, J. M. C.: Novel iodine chemistry in the marine boundary layer, Geophys. Res. Lett., 31(4), L04112, doi:10.1029/2003GL019215, 2004.

Saiz-Lopez, A., Shillito, J. A., Coe, H., and Plane, J. M. C.: Measurements and modelling of $\mathrm{I} 2, \mathrm{IO}, \mathrm{OIO}, \mathrm{BrO}$ and $\mathrm{NO} 3$ in the mid-latitude marine boundary layer, Atmos. Chem. Phys., 6(6), 1513-1528, doi:10.5194/acp-6-1513-2006, 2006.

Saiz-Lopez, A., Mahajan, A. S., Salmon, R. A., Bauguitte, S. J.B., Jones, A. E., Roscoe, H. K., and Plane, J. M. C.: Boundary Layer Halogens in Coastal Antarctica, Science, 317, 348-351, doi:10.1126/science.1141408, 2007.

Saiz-Lopez, A., Plane, J. M. C., Mahajan, A. S., Anderson, P. S., Bauguitte, S. J.-B., Jones, A. E., Roscoe, H. K., Salmon, R. A., Bloss, W. J., Lee, J. D., and Heard, D. E.: On the vertical distribution of boundary layer halogens over coastal Antarctica: implications for $\mathrm{O}_{3}, \mathrm{HO}_{\mathrm{x}}, \mathrm{NO}_{\mathrm{x}}$ and the $\mathrm{Hg}$ lifetime, Atmos. Chem. Phys., 8, 887-900, doi:10.5194/acp-8-887-2008, 2008.

Saiz-Lopez, A., Plane, J. M. C., Baker, A. R., Carpenter, L. J., von Glasow, R., Martín, J. C. G., McFiggans, G., and Saunders, R. W.: Atmospheric chemistry of iodine., Chem. Rev., 112, 1773804, doi:10.1021/cr200029u, 2012a.

Saiz-Lopez, A., Lamarque, J.-F., Kinnison, D. E., Tilmes, S., Ordóñez, C., Orlando, J. J., Conley, A. J., Plane, J. M. C., Mahajan, A. S., Sousa Santos, G., Atlas, E. L., Blake, D. R., Sander, S. P., Schauffler, S., Thompson, A. M., and Brasseur, G.: Estimating the climate significance of halogen-driven ozone loss in the tropical marine troposphere, Atmos. Chem. Phys., 12, 3939-3949, doi:10.5194/acp-12-3939-2012, 2012 b.

Sakamoto, Y., Yabushita, A., Kawasaki, M., and Enami, S.: Direct emission of $I_{2}$ molecule and IO radical from the heterogeneous reactions of gaseous ozone with aqueous potassium iodide solution., J. Phys. Chem. A, 113, 7707-7713, doi:10.1021/jp903486u, 2009.

Salawitch, R. J., Weisenstein, D. K., Kovalenko, L. J., Sioris, C. E., Wennberg, P. O., Chance, K., Ko, M. K. W., and McLinden, C. A.: Sensitivity of ozone to bromine in the lower stratosphere, Geophys. Res. Lett., 32, L05811, doi:10.1029/2004GL021504, 2005.

Sander, R.: Compilation of Henry's Law Constants for Inorganic and Organic Species of Potential Importance in EnvironmentalChemistry (v3), available at: http://www.henrys-law.org/ (last access: 28 May 2014), 1999.

Sander, S. P., Friedl, R. R., Golden, D. M., Kurylo, M. J., Moortgat, G. K., Wine, P. H., Ravishankara, A. R., Kolb, C. E., Molina, M. J., Diego, S., Jolla, L., Huie, R. E., and Orkin, V. L.: Chemical Kinetics and Photochemical Data for Use in Atmospheric Studies 
Evaluation Number 15, JPL_NASA, 06-2, Jet Propulsion Laboratory, Pasadena, CA, 2006.

Sander, S. P., Friedl, R. R., Barker, J. R., Golden, D. M., Kurylo, M. J., Sciences, G. E., Wine, P. H., Abbatt, J. P. D., Burkholder, J. B., Kolb, C. E., Moortgat, G. K., Huie, R. E., and Orkin, V. L.: Chemical Kinetics and Photochemical Data for Use in Atmospheric Studies, Evaluation No. 17, JPL_NASA, 10-6, Jet Propulsion Laboratory, Pasadena, CA, 2011.

Saunders, R. W. and Plane, J. M. C.: Formation Pathways and Composition of Iodine Oxide Ultra-Fine Particles, Environ. Chem., 2, 299, doi:10.1071/EN05079, 2005.

Saunders, R. W., Kumar, R., Gómez Martín, J. C., Mahajan, a. S., Murray, B. J., and Plane, J. M. C.: Studies of the Formation and Growth of Aerosol from Molecular Iodine Precursor, Zeitschr. Phys. Chemie, 224, 1095-1117, doi:10.1524/zpch.2010.6143, 2010.

Schwartz, S. E. and Warneck, P.: Units for use in Atmospheric Chemistry, Pure Appl. Chem., 67, 1377-1406, 1995.

Solomon, S., Garcia, R. R., and Ravishankara, A. R.: On the role of iodine in ozone depletion, J. Geophys. Res., 99, 20491, doi:10.1029/94JD02028, 1994.

Sommariva, R. and von Glasow, R.: Multiphase halogen chemistry in the tropical Atlantic Ocean., Environ. Sci. Technol., 46, 10429-10437, doi:10.1021/es300209f, 2012.

Sommariva, R., Bloss, W. J., and von Glasow, R.: Uncertainties in gas-phase atmospheric iodine chemistry, Atmos. Environ., 57, 219-232, doi:10.1016/j.atmosenv.2012.04.032, 2012.

Spietz, P., Gómez Martín, J. C., and Burrows, J. P.: Spectroscopic studies of the $\mathrm{I} 2 / \mathrm{O} 3$ photochemistry Part 2. Improved spectra of iodine oxides and analysis of the IO absorption spectrum, J. Photochem. Photobiol. A Chem., 176, 50-67, doi:10.1016/j.jphotochem.2005.08.023, 2005.
Tegtmeier, S., Krüger, K., Quack, B., Atlas, E., Blake, D. R., Boenisch, H., Engel, A., Hepach, H., Hossaini, R., Navarro, M. A., Raimund, S., Sala, S., Shi, Q., and Ziska, F.: The contribution of oceanic methyl iodide to stratospheric iodine, Atmos. Chem. Phys., 13, 11869-11886, doi:10.5194/acp-13-11869-2013, 2013.

Vogt, R., Sander, R., von Glasow, R., and Crutzen, P. J.: Iodine Chemistry and its Role in Halogen Activation and Ozone Loss in the Marine Boundary Layer: A Model Study, J. Atmos. Chem., 32, 375-395, doi:10.1023/A:1006179901037, 1999.

Wegner, T., Kinnison, D. E., Garcia, R. R., and Solomon, S.: Simulation of polar stratospheric clouds in the specified dynamics version of the whole atmosphere community climate model, J. Geophys. Res. Atmos., 118, 4991-5002, doi:10.1002/jgrd.50415, 2013.

Young, P. J., Archibald, a. T., Bowman, K. W., Lamarque, J.-F., Naik, V., Stevenson, D. S., Tilmes, S., Voulgarakis, a., Wild, O., Bergmann, D., Cameron-Smith, P., Cionni, I., Collins, W. J., Dalsøren, S. B., Doherty, R. M., Eyring, V., Faluvegi, G., Horowitz, L. W., Josse, B., Lee, Y. H., MacKenzie, I. a., Nagashima, T., Plummer, D. a., Righi, M., Rumbold, S. T., Skeie, R. B., Shindell, D. T., Strode, S. a., Sudo, K., Szopa, S., and Zeng, G.: Preindustrial to end 21 st century projections of tropospheric ozone from the Atmospheric Chemistry and Climate Model Intercomparison Project (ACCMIP), Atmos. Chem. Phys., 13, 2063 2090, doi:10.5194/acp-13-2063-2013, 2013. 